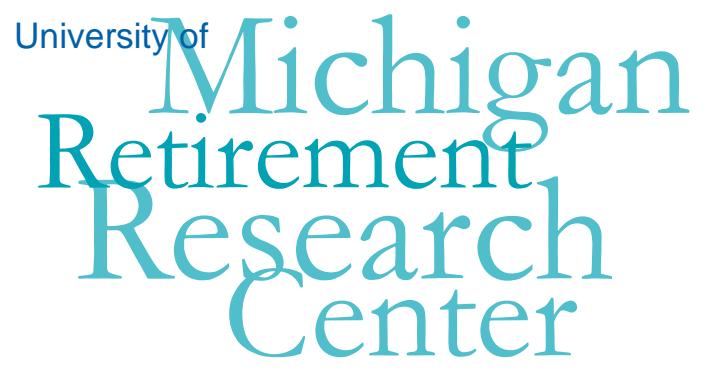

Working Paper

WP 2011-259

\title{
Macroeconomic Conditions and Updating of Expectations by Older Americans
}

\author{
Purvi Sevak and Lucie Schmidt
}

\begin{tabular}{|l|l|}
\hline $\mathrm{M}$ & $\mathrm{R}$ \\
\hline $\mathrm{R}$ & $\mathrm{C}$ \\
\hline
\end{tabular}

Project \#: UM11-13 



\title{
Macroeconomic Conditions and Updating of Expectations by Older Americans
}

\author{
Purvi Sevak \\ Hunter College \\ Lucie Schmidt \\ Williams College \\ November 2011 \\ Michigan Retirement Research Center \\ University of Michigan \\ P.O. Box 1248 \\ Ann Arbor, MI 48104 \\ http://www.mrrc.isr.umich.edu
}

(734) 615-0422

\section{Acknowledgements}

This work was supported by a grant from the Social Security Administration through the Michigan Retirement Research Center (Grant \# RRC08098401-03-00). The findings and conclusions expressed are solely those of the author and do not represent the views of the Social Security Administration, any agency of the Federal government, or the Michigan Retirement Research Center.

\section{Regents of the University of Michigan}

Julia Donovan Darrow, Ann Arbor; Laurence B. Deitch, Bingham Farms; Denise Ilitch, Bingham Farms; Olivia P. Maynard, Goodrich; Andrea Fischer Newman, Ann Arbor; Andrew C. Richner, Grosse Pointe Park; S. Martin Taylor, Gross Pointe Farms; Katherine E. White, Ann Arbor; Mary Sue Coleman, ex officio 


\title{
Macroeconomic Conditions and Updating of Expectations by Older Americans
}

\begin{abstract}
Economic theory suggests that individual decisions about consumption, saving, and labor supply should be directly linked to subjective expectations about future events. This project uses panel data from the Health and Retirement Study from 1994-2008 merged to data on a number of local and high frequency macroeconomic indicators to estimate how individual expectations respond to fluctuations in the local and national macroeconomy. Our results suggest that individuals revise their expectations in response to both local and national macroeconomic fluctuations in ways that appear to make sense, and that this is stronger for respondents with higher levels of education.
\end{abstract}

\section{Author Acknowledgements}

We are grateful to Partha Deb, Sara LaLumia and Sangeeta Pratap for helpful comments and conversations. Contact information: Department of Economics, Schapiro Hall, Williams College, Williamstown, MA 01267, email: 1schmidt@williams.edu 


\section{Introduction}

Economic theory suggests that individuals’ decisions about consumption, saving, and labor supply should be directly linked to subjective expectations about future events. Because of this, a growing literature has emerged that examines individuals’ subjective probability expectations, aided by an expanded set of household surveys that ask questions to elicit expectations of respondents. A great deal of research has been done in recent years validating these questions as predictors of future behavior. However, much less attention has been paid to how individuals form and update their expectations. Expectations of older cohorts of individuals are particularly important to examine, given the importance these expectations are likely to play in retirement planning and timing decisions that are costly to reverse.

In this project we investigate expectation formation, using data from the 1994-2008 Health and Retirement Study, linked to data on local and national macroeconomic conditions collected from a number of data sets. We look at two types of subjective expectations questions - those related to macroeconomic and policy conditions, and those related to individual-level situations such as labor supply and household wealth. We examine the relationship between demographic characteristics and these expectations. We then examine how local and national macroeconomic conditions affect retirement expectations and other subjective probability measures. We also explore whether there is heterogeneity in how individuals update their expectations in response to macroeconomic conditions by educational status. Our preliminary results suggest that respondents do revise their subjective expectations in response to local and national economic conditions in ways that generally make sense. We also find that collegeeducated individuals are more likely to make such revisions. 


\section{Background}

Individuals’ expectations of uncertain future outcomes should be important determinants of their behavior. Because of this, a growing literature has emerged that examines individuals’ subjective probability expectations. These subjective expectations, on average, appear to approximate actual mean risks in the population for a number of different measures. For example, there is a strong relationship between subjective survival probabilities and subsequent mortality rates (Hurd and McGarry, 2002; Smith et al., 2001), expectations of retirement timing and actual retirement timing (e.g. Bernheim, 1989; Disney and Tanner, 1999; Loughran et al., 2001; and Haider and Stephens, 2007), expected retirement savings questions and actual retirement saving (Haider and Stephens, 2006), and expectations of job loss and actual job displacements (Stephens, 2004). Although expectations have been found to approximate actual mean risks in the population, a great degree of variation exists in how individuals report expectations. Individual responses are often "heaped” on focal values of “0”, “50”, and “100” (Lillard and Willis, 2001). Lillard and Willis argue that this pattern of responses could reflect respondents’ uncertainty about true values of probabilities.

Another thread of this literature has examined how expectations are formed, and the extent to which individuals incorporate new information when they revise expectations. Overall, evidence from a number of different contexts suggests that individuals do revise expectations in response to new information in systematic ways (see Dominitz (1998) on earnings expectations; Benitez-Silva and Dwyer (2005) on retirement age expectations; Lochner (2007) on arrest probabilities; Delavande (2008) on the effectiveness of contraceptive methods; and Zafar (2011) on college students’ academic expectations). ${ }^{1}$ However, most of this literature does not allow for

\footnotetext{
${ }^{1}$ Benitez-Silva and Dwyer (2005) conduct a test of whether individual retirement age expectations are consistent with the rational expectations hypothesis. While they examine how changes in individual health and income affect expectations, they do not consider how individuals incorporate changing macroeconomic conditions.
} 
heterogeneity in the response of expectations to new information. One important exception is Delavande (2008), which finds that schooling and knowledge and use of birth control methods significantly affect how expectations regarding contraceptive efficacy are revised.

A number of papers have tested whether, consistent with economic theory, households' behavior responds to unexpected changes in wealth (Anderson et al. (1986); Coile and Levine (2006, 2009), Sevak (2003), Hurd et al. (2009), Coronado and Perozek (2003)). However, there is little guidance available to determine households' expectations and how these expectations vary over time. For example, in their recent study of the effects of unemployment, financial markets and housing markets on retirement, Coile and Levine (2009) note, "While it is plausible that expectations about house price appreciation may vary by location, we have no data to guide us on this point, so we must treat all gains or losses in all locations as (equally) unanticipated.” Given the large swings in the stock market and housing markets in recent years, it is even more important to understand how the retirement age population forms and updates their expectations. Our paper contributes to this literature by examining the role that changing economic conditions play in the updating of expectations by individuals. In addition, we are also able to examine the extent to which individual-level heterogeneity might be important in expectations updating. While our current findings are descriptive in nature, they suggest that there is substantial heterogeneity across individuals and over time in expectations about the future economic environment. In addition, individuals seem to incorporate news about recent economic variables in their expectations. Researchers modeling labor supply or consumption effects of income shocks or other surprises could improve the precision of their estimates by incorporating heterogeneous expectations into their models. 


\section{Data and Analysis}

We use data from the Health and Retirement Study (HRS) for the years 1994 to 2008. The HRS is a nationally representative panel of individuals near retirement age collected by the Survey Research Center at the University of Michigan. ${ }^{2}$ A baseline set of about 12,000 individuals who were born between 1931 and 1941 (or married to someone born between 1931 and 1941) was first interviewed in 1992. Every two years, the HRS attempts to re-interview the members of this household. If a subject refuses to conduct an interview or is unreachable in one wave, the HRS continues to interview him or her in subsequent waves until the individual has died. To keep the sample representative of the population close to retirement age, the HRS adds younger cohorts to the study every six years. In this study, we include these younger cohorts once they enter the sample in 1998 and 2004.

In each interview year, respondents answer detailed questions about current and past labor supply, health, and other topics. A designated “financial respondent” in each household provides detailed financial information on the household, including values of various assets, such as housing, real estate, stocks, bonds, checking and savings accounts, and individual retirement accounts (IRAs), along with income. Since assets are reported at the household level and cannot be attributed to one particular spouse, we measure wealth and income at the household level and assume that households pool their resources.

The HRS asks a number of expectations questions in each wave. Both partners in married households are asked these questions. While many questions were not asked at the baseline interview, all questions have been asked for multiple waves, allowing us to utilize multiple responses across years for a given respondent. We examine a number of different expectation questions that can be categorized into two groups. A set of macroeconomic and public policy

\footnotetext{
${ }^{2}$ Detailed information on the HRS data is available at http://hrsonline.isr.umich.edu/data/index.html.
} 
questions includes respondent-reported probabilities that the U.S. economy will have a major depression within the next ten years; that mutual fund shares invested in blue chip stocks will rise in value over the next year; that Social Security will become less generous; and that there will be double-digit inflation within the next ten years. A second set of questions related to individual-level situations includes respondent-reported probabilities of working full time after age 62 and 65 (asked of those respondents younger than age 61 and 64, respectively); of leaving an inheritance of $\$ 10,000$; and of medical expenses using up all of the respondent's savings in the next five years. The Data Appendix provides exact wording of these expectation questions and the years in which each question was asked.

To the HRS, we merge data on monthly state unemployment rates from the Bureau of Labor Statistics, and quarterly state level house prices indices (HPI) from the Federal Housing Finance Agency (formerly the Office of Federal Housing Enterprise and Oversight (OFHEO)). We also merge monthly stock price data from the S\&P 500, monthly retail sales data, and quarterly data on job creation/loss at the state level. To do this, we exploit the fact that through restricted access, HRS makes available the month an individual respondent's interview began along with their state of residence. ${ }^{3}$ This allows us to more precisely match local and national economic conditions at the time of the interview. The fact that within a particular HRS interview year, individual households are interviewed at different times - most over a span of six months allows us greater variation with which to estimate responses. Detailed source information for these variables can be found in the Data Appendix.

We use these data to estimate a series of regressions for each subjective expectation as a dependent variable. We examine the relationship between expectations and a number of different individual level demographic characteristics, including age, gender, race and Hispanic

${ }^{3}$ More information is available at http://hrsonline.isr.umich.edu/rda/ 
ethnicity, married/partner status, and education level. We also control for both physical and mental health (whether a respondent reported poor health, whether they reported that their health had worsened in the past two years, and whether their responses to a series of mental health questions indicated poor mental health). Finally, we control for financial wealth, business wealth, housing wealth, the log of family income, and whether the respondent is a renter. Our regressions control for state fixed effects, and we compute robust standard errors.

We then add dummy variables for the year of the HRS wave to capture changes in macroeconomic conditions over time that affect all individuals nationwide. We then add the monthly and quarterly macroeconomic measures mentioned above, many which are at the local level, to test whether subjective expectations vary with local and higher frequency macroeconomic indicators. Finally, we interact some of our local economic condition variables with an indicator for college-educated, to test whether the updating of expectations by households in response to these conditions varies by education level. ${ }^{4}$

Table 1 presents summary statistics for our sample, which consists of 102,819 respondent-wave observations. Any one probability measure is reported for a subsample of this sample, due to the fact that most of the probability questions were not asked in all the waves, and that some were asked only of respondents under age 62 or 65 . For all variables, we report means and standard deviations. On average, HRS respondents have relatively high expectations of the macroeconomic events they are asked about. The average probability responses for a depression and double-digit inflation are just under 50 percent, similar to the average given for an increase in stock prices. The average probability response for a less generous Social Security system is over 60 percent. The average expectation provided by those under 61 on the probability of

\footnotetext{
${ }^{4}$ We have also interacted the local and high frequency economic conditions with an indicator for whether the respondent is over 65. There are no significant differences in responses to these conditions by age, so we do not present these results. Results available from corresponding author by request.
} 
working full time past the age of 62 is almost $50 \%$, whereas the expected probability given for working past the age of 65 is significantly lower. The respondents have relatively high expectations of leaving a bequest of at least $\$ 10,000$ (average probability $69 \%$ ) and relatively low expectations of medical expenses exhausting their savings (average probability 28\%).

However, these averages mask a great deal of heterogeneity of responses to these expectation questions. For example, Figure 1 graphs out the entire distribution of responses for the subjective probability of a depression in the next ten years. As was noted by Lillard and Willis (2001), the distribution shows a significant level of heaping on "focal" responses of 0,50 , and 100, with additional heaping on probabilities divisible by 5 and 10 . Figures 2-8 provide similar distributions for the remaining seven expectation questions. While all eight graphs provide evidence of heaping, there are interesting differences that emerge. The distribution of responses for the expectation of a less generous Social Security system is much more heavily distributed towards higher probabilities, while the distribution for the other macro and policy expectation questions is much more evenly distributed. The expectation questions that are less under the control of the respondents or that are more difficult to predict exhibit a greater degree of heaping on 50, consistent with research that suggests that answers of "50 percent” may reflect greater levels of uncertainty and be more similar to the meaning of a "50/50 chance" as used in daily language (e.g. Bruine de Bruin et al., 2000)

The average age among our respondents is 61.7 , and slightly fewer than half are male. $35 \%$ have a two year college degree or higher education, and $41 \%$ have a high school diploma as their highest degree. $16 \%$ are Black, $9 \%$ are Hispanic, and $75 \%$ are married or partnered. Over a quarter of the sample reports that they are in poor health, and 14 percent have a mental health problem. Only $17 \%$ are renters. 
Summary statistics for macroeconomic variables, measured in the period (month or quarter) before a respondent was interviewed, reflect fairly typical values, such as a mean state unemployment rate of 5\% and (CPI adjusted) house prices increasing just over 2 percent per year. The distribution of macroeconomic indicators is not surprising given the long panel in the sample from 1994 to 2008. While there are respondents who were interviewed when unemployment rates were much higher and the S\&P 500 fell sharply, such as in the last few months of 2008, the sample period is long enough that these are not reflected in the mean or the quartiles.

\section{Results}

Expectations of Macroeconomic and Policy Conditions

Table 2 presents regressions predicting subjective expectations related to macroeconomic and policy expectations. Column 1 looks at determinants of the subjective expectations of the probability that we enter a major depression in the next ten years. Older individuals have significantly lower expectations of entering a depression, as do men, married individuals, and individuals in better financial positions in terms of both income and wealth. High school graduates, blacks, renters, and those in poor and declining physical and mental health have significantly higher expectations of entering a recession.

Column 2 provides similar results for the subjective probability that Social Security will become less generous. Men have higher expectations of a less generous Social Security system, as do both college and high school graduates (relative to the omitted category of high school dropouts), and those in declining physical health and with poor mental health. Blacks, Hispanics, married and partnered individuals, and renters are more optimistic about Social Security generosity. Age does not have a significant effect on this expectation. 
Column 3 looks at subjective expectations that mutual fund shares invested in blue chip stocks will rise in value over the next year. Older individuals, men, college and high school graduates, and those with higher incomes and housing wealth have significantly higher expectations that stock prices will increase in the next year. Blacks and Hispanics, those in poor and declining physical and mental health, and renters have significantly lower expectations of an increase in stock prices. These patterns could reflect differential familiarity with the stock market due to demographic and educational differences in stock ownership.

Column 4 examines subjective expectations of double-digit inflation in the next ten years. Older individuals have higher expectations (approaching statistical significance at the ten-percent level) of double-digit inflation, as do high school graduates (compared with the omitted category of dropouts), individuals in poor and declining physical and mental health, and those with higher levels of business wealth. Men, college graduates, blacks, Hispanics, and those with higher levels of financial wealth have significantly lower expectations of double-digit inflation.

The one interesting pattern of effects that emerges across the various expectation measures in Table 2 is that individuals in poor health are consistently more pessimistic about macroeconomic and policy conditions. They have higher expectations of a major depression, high inflation, a less generous Social Security system, and lower expectations of an increase in stock prices. For all other characteristics, there does not appear to be a pattern that is consistent with either a general optimism or pessimism towards the economy. Most demographic and socioeconomic characteristics are associated with higher expectations of both "positive" and "negative” economic outcomes. For example, men have lower expectations of a depression or high inflation and higher expectations of stock price increases, but also have higher expectations that Social Security will be less generous. Similar patterns hold for those with higher income. 
Table 3 adds year fixed effects. The reference year is always the first HRS year in which the probability measure was asked - in most cases this is 1994, but exceptions are noted in the table. The year fixed effects can be thought of as capturing the effect of annual macroeconomic conditions at the national level. In almost all cases, the year fixed effects reduce the magnitude and statistical significance of the age variables, suggesting that some of the correlation found in the previous table was due to changes over time and not age per se. The effects of most other demographic variables remain largely unchanged. There is also some evidence of an increase in pessimism with the onset of the current economic downturn. The 2008 year fixed effect suggests that, relative to the reference year of 1994, respondents reported a 21 percentage point greater probability of a major depression in ten years. Respondents also reported a slightly higher probability (one percentage point) of Social Security becoming less generous.

Table 4 adds in local macroeconomic conditions and higher frequency measures. Column 1 shows that higher state unemployment rates and a decrease in stock prices are associated with a significant increase in the expected probability of a depression in ten years. An increase in the state unemployment rate of one percentage point is associated with a 1.35 percentage point higher reported probability of depression. For stock prices, a 10\% increase in the average S\&P 500 closing value is associated with a 1.16 percentage point increase in reported probability of depression. Surprisingly, an increase in the house price index is also positively and significantly associated with an increased expectation of a depression. While these estimates are statistically significant, they are relatively small in magnitude.

For the expectation of a less generous Social Security system, local unemployment rates have a significant effect, with higher unemployment rates associated with a higher probability of less generous Social Security. In addition, a larger increase in retail sales prices is significantly associated with higher expectations of less generous Social Security. Again, the magnitudes are 
relatively small. In Column 3, we find that a monthly increase in stock prices is significantly associated with a decreased expectation of a future stock price increase. This suggests that in periods when stock prices have fallen, individuals are more likely to believe they will subsequently rise, which could be consistent with individuals believing in some degree of mean reversion in stock prices. In Column 4, we see that only an increase in job gains is significantly associated with inflation expectations, with higher job gains leading to higher expectations of double-digit inflation.

Table 5 tests for the heterogeneity of the response to local macroeconomic conditions by including interactions of these variables with an indicator for being a college graduate. For college graduates, there is a stronger relationship between local economic conditions and the expected probability of a depression. The effect of an increase in the unemployment rate on the expected probability of a depression is twice the magnitude for college graduates than for respondents with lower levels of education. College graduates revise their expectations of a depression upward in response to an increase in job losses, a decrease in retail prices, and an increase in housing prices. However, college graduates are less likely to revise their expectations of a less generous Social Security system - estimated effects of job losses and stock prices only show up for the less educated respondents. Only college graduates revise their expectations of mutual fund increases upward in response to an increase in either retail prices or house prices. And the positive and significant effect of the unemployment rate on expected inflation exists for college graduates only. This finding may be surprising given that fears of inflation are often associated with periods of low unemployment. However, these individuals did live through a period of stagflation in the 1970s where high unemployment was accompanied by high inflation, so perhaps this is reflected in their expectation formation. 


\section{Expectations of Personal Work and Financial Situations}

Table 6 presents the determinants of expectations of the individual-level situations related to labor supply and financial wealth. Column 1 looks at the expected probability of working full-time after the age of 62, among respondents younger than age 61. Older individuals are significantly less likely to expect to work after 62, as are blacks, Hispanics, married respondents, and those in poor and declining physical and mental health. Men, college and high school graduates, those with higher incomes, and renters are significantly more likely to expect to work at age 62. There does appear to be a wealth effect on expected labor supply, as those with higher financial wealth have significantly lower expectations of working past the age of 62, ceteris paribus. The results in Column 2, looking at the expected probability of working past the age of 65 , among respondents younger than age 64 , show exactly the same patterns.

Column 3 presents the determinants of the expected probability of leaving a bequest of $\$ 10,000$ or more. Older individuals, men, college and high school graduates, and those with higher income and higher financial, business, and housing wealth all have higher expectations of leaving a bequest. Blacks and Hispanics, those in poor and declining physical and mental health, and renters have significantly lower expectations of leaving a bequest. Column 4 looks at expectations that medical expenses will exhaust respondent savings in the next five years. Not surprisingly, many of the characteristics that are associated with higher subjective probability of leaving a bequest are associated with lower subjective probability of exhausting their savings. Blacks, married respondents, those in poor and declining physical and mental health, and renters are significantly more likely to expect medical expenses will exhaust their savings, while men, college graduates, and those with higher levels of income and financial and housing wealth have lower expectations of this occurring. 
Table 7 adds year fixed effects, with 1994 being the reference period. The year effects are consistent with respondents' expectations of working later in life growing continually from year to year over our sample. Given that the stock and labor markets did not tumble until the latter part of 2008, it is not surprising that respondents report greater bequest probabilities (relative to 1994) and lower probabilities of exhausting their savings (relative to 2004) in both 2006 and 2008.

Table 8 adds in the local and high frequency economic conditions. In Column 1, only the house price index is significantly associated with the expected probability of working past the age of 62, with an increase in house prices slightly reducing respondents' expectations of working full time past this age. In Column 2, we see that the expectation of working past the age of 65 is more responsive to these economic conditions. A one percentage point increase in the unemployment rate is associated with about a 0.7 percentage point increase in the probability of working. A decrease in job gains has an effect of similar magnitude. The house price effect found in Column 1 also exists for the probability of working past the age of 65. Column 3 finds no significant effects of local and high frequency economic conditions on the expected probabilities of leaving a bequest. In Column 4, we see a counterintuitive, positive, though small, coefficient on changes in house prices, suggesting that when house prices rise, respondents report higher chances of medical expenses exhausting their savings.

Table 9 interacts the local and high frequency economic conditions with an indicator for whether the respondent is a college graduate. Column 1 shows no heterogeneity in effects for the expected probability of working past the age of 62. However, results in Column 2 suggest that the unemployment rate effect found in the previous table is larger for less-educated individuals, while the house price effect is larger for more-educated individuals. This is consistent with the fact that college graduates are less likely to be affected by business cycle 
fluctuations, and more likely to be homeowners. Column 3 shows that the zero effect of house prices on bequest probabilities found in the previous table masks offsetting effects by education status. For the overall population, higher increases in house prices lead to significantly higher probabilities of leaving a bequest. However, for the college graduates, a negative and significant interaction term completely offsets this effect. In Column 4, we find that higher increases in stock prices lead to a significant decrease in the expectation of medical expenses exhausting savings, but for college graduates only.

\section{Summary}

In this paper, we investigate the formation of two types of expectations - those related to macroeconomic conditions and policy, and those related to individual-level situations like labor supply and financial wealth. We find strong correlations between a number of demographic characteristics and individuals' expectations. Individuals in poor and declining physical and mental health have significantly less optimistic expectations about the macroeconomic future. Individuals from more vulnerable socioeconomic groups have lower expected probabilities of leaving bequests and higher expected probabilities of having medical expenses use up their savings. However, they are also significantly less likely to expect to be working past age 62 or 65, which could have important implications for their economic well-being. We find evidence that suggests that HRS respondents update their expectations in response to local and high frequency macroeconomic conditions in ways that seem to make sense, and that this is stronger for respondents with higher levels of education.

In many cases, a family’s future financial well-being depends on its members' ability to obtain, understand and update their expectations and resulting behavior to changes in the economic environment. Our results provide an important contribution to our understanding of 
how individual expectations are shaped by fluctuations in the macroeconomy. They suggest that researchers modeling how individuals alter their behavior in response to macroeconomic fluctuations could benefit from incorporating heterogeneous expectations into their models. 


\section{References}

Anderson, Kathryn H., Richard V. Burkhauser, and Joseph F. Quinn. 1986. “Do Retirement Dreams Come True? The Effect of Unanticipated Events on Retirement Plans.” Industrial and Labor Relations Review, 39(4): 518-526.

Benítez-Silva, Hugo, and Debra S. Dwyer. 2005. “The Rationality of Retirement Expectations and the Role of New Information.” Review of Economics and Statistics 87(3): 587-592.

Bernheim, B. Douglas. 1989. "The Timing of Retirement: A Comparison of Expectations and Realizations,” in David A. Wise (Ed.), The Economics of Aging (Chicago and London: University of Chicago Press).

Bruine de Bruin, Wändi, Baruch Fischhoff, Shana G. Millstein, and Bonnie L. Halpern-Felsher. 2000. "Verbal and Numerical Expressions of Probability: It’s a Fifty-Fifty Chance.” Organizational Behavior and Human Decision Processes 81(1), 115-131.

Coile, Courtney C., and Phillip B. Levine. 2009. “The Market Crash and Mass Layoffs: How the Current Economic Crisis May Affect Retirement.” National Bureau of Economic Research Working Paper 15395.

Coile, Courtney C., and Phillip B. Levine. 2006. "Bulls, Bears, and Retirement Behavior.” Industrial and Labor Relations Review 59(3): 408-429.

Coronado, Julie, and Maria Perozek. 2003. "Wealth Effects and the Consumption of Leisure: Retirement Decisions During the Stock Market Boom of the 1990s,” Board of Governors of the Federal Reserve System, Finance and Economics Discussion Series \#2003-20.

Delavande, Adeline. 2008. “Measuring Revisions to Subjective Expectations.” Journal of Risk and Uncertainty 6(1): 43-82.

Disney, Richard, and Sarah Tanner. 1999. "What Can We Learn From Retirement Expectations Data?” The Institute for Fiscal Studies Working Paper Series No. W99/17.

Dominitz, Jeff. 1998. “Earnings Expectations, Revisions, and Realizations.” Review of Economics and Statistics 80(3): 374-388.

Haider, Steven J., and Melvin Stephens Jr. 2007. “Is There a Retirement-Consumption Puzzle? Evidence Using Subjective Retirement Expectations.” Review of Economics and Statistics 89(2): 247-264.

Haider, Steven J., and Mel Stephens Jr. 2006. “How Accurate are Expected Retirement Savings?” Michigan Retirement Research Center WP 2006-128.

Hurd, Michael D., Monika Reti, Susann Rohwedder. 2009. "The Effect of Large Capital Gains or Losses on Retirement", in David Wise (ed.), Developments in the Economics of Aging. Chicago: University of Chicago Press. 
Hurd, Michael D., and Kathleen McGarry. 2002. “The Predictive Validity of Subjective Probabilities of Survival,” Economic Journal 112: 966-985.

Lillard, Lee A., and Robert J. Willis. 2001. "Cognition and Wealth: The Importance of Probabilistic Thinking,” University of Michigan Manuscript.

Lochner, Lance. 2007. "Individual perceptions of the criminal justice system.” American Economic Review 97(1):444-60.

Loughran, David, Constantijn Panis, Michael Hurd, and Monika Reti (2001). "Retirement Planning,” RAND Manuscript.

Sevak, Purvi. 2003. "Wealth Shocks and Retirement Timing: Evidence from the Nineties." Michigan Retirement Research Center Working Paper WP00D1.

Smith, V. Kerry, Donald H. Taylor Jr., and Frank A. Sloan. 2001. "Longevity Expectations and Death: Can People Predict Their Own Demise?” American Economic Review 91: 11261134.

Stephens Jr., Melvin. 2004. "Job Loss Expectations, Realizations, and Household Consumption Behavior.” Review of Economics and Statistics 86: 253-269.

Zafar, Basit. 2011. "How Do College Students Form Expectations?” Journal of Labor Economics 29(2): 301-348. 


\section{Data Appendix}

Health and Retirement Study Variables

The expectations variables in the HRS are based on responses to the following questions in the years specified:

What do you think are the chances that the U.S. economy will experience a major depression sometime during the next 10 years or so? $(1994,1996,1998,2004,2006,2008)$

By next year at this time, what is the percent chance that mutual fund shares invested in blue chip stocks like those in the Dow Jones Industrial Average will be worth more than they are today? (2002, 2004, 2006, 2008)

How about the chances that congress will change Social Security so that it becomes less generous than now? $(1996,1998,2006,2008)$

And how about the chances that the U.S. economy will experience double-digit inflation sometime during the next 10 years or so? $(1994,1996,1998,2000)$

What do you think the chances are that you will be working full-time after you reach age 62? (1994, 1996, 1998, 2000, 2002, 2004, 2006, 2008)

And what about the chances that you will be working full-time after you reach age 65 ? (1994, 1996, 1998, 2000, 2002, 2004, 2006, 2008)

And what are the chances that you (and your husband/and your wife/and your partner) will leave an inheritance totaling $\$ 10,000$ or more? $(1994,1996,1998,2000,2002,2004,2006$, 2008)

What do you think are the chances that medical expenses will use up all your savings in the next five years? $(2004,2006,2008)$

\section{High Frequency Macroeconomic Variables:}

Quarterly job gains and job losses:

Business Employment Dynamics (BD) data from the Bureau of Labor Statistics (http://www.bls.gov/bdm/). Data are available by state at the quarterly level from 1992 Q3 through 2010 Q2 (Data for the District of Columbia begin in 2000). These data are derived from the Covered Employment and Wages Program, also known as the ES-202 program. It is the quarterly census of all establishments under State unemployment insurance programs, representing about $98 \%$ of employment on nonfarm payrolls. The data include all establishments subject to State unemployment insurance (UI) laws and all Federal agencies subject to the Unemployment Compensation for Federal Employees (UCFE) program. Rates measure gross job gains and losses as a percentage of the average of the previous and current quarter employment. We use seasonally adjusted data 
Monthly unemployment rates:

We collect monthly unemployment rates at the state level from the Bureau of Labor Statistics Local Area Unemployment Statistics (LAUS) (http://www.bls.gov/lau/). Unemployment rates are seasonally adjusted.

Monthly retail sales data:

Data on total retail and food services sales at the national level come from the Census Bureau's Monthly and Annual Retail Trade Report (http://www.census.gov/retail/\#mrts). Data are reported in millions of dollars and are based on data from the Monthly Retail Trade Survey and administrative records. Estimates are adjusted for seasonal variations and holiday and trading day differences, but not for price changes.

Monthly S\&P 500 price data:

Data come from Robert Shiller (http://www.econ.yale.edu/ shiller/data.htm) and are the same series used in the book Irrational Exuberance. Stock price data are monthly averages of daily closing prices

\section{Quarterly house price index data:}

Data come from the Office of Federal Housing Enterprise Oversight (FHFA). FHFA calculates quarterly house price indices (HPI) using data on repeat sales of single-family homes. These data are provided to FHFA by Freddie Mac and Fannie Mae and are based on sales of homes with standard mortgages. The HPI is a weighted average, across actual houses, of changes in house prices. Because it relies on repeat sales, it is a "constant quality" index. It avoids most problems of a changing quality of housing stock that occur when one looks just at average sales prices of homes over time. We adjust the measures by the CPI so house price changes are net of overall inflation. A full technical description of the HPI is available at http://www.FHFA.gov/Media/Archive/house/hpi_tech.pdf. 
Table 1: Summary Statistics: HRS Respondents 1994-2008

\begin{tabular}{|c|c|c|}
\hline & Mean & Std Dev \\
\hline \multicolumn{3}{|l|}{ Subjective Probability Reported } \\
\hline Major Depression in 10 Years & 45.32 & 29.79 \\
\hline Social Security Less Generous & 61.51 & 28.83 \\
\hline Mutual Funds Worth More Next Year & 48.63 & 26.35 \\
\hline Double Digit Inflation in 10 Years & 47.92 & 28.11 \\
\hline Work Full Time at Age 62 & 45.82 & 38.12 \\
\hline Work Full Time at Age 65 & 27.88 & 33.68 \\
\hline Leave a Bequest of $\$ 10,000+$ & 69.10 & 38.88 \\
\hline Medical Expenses Exhaust Savings in 5 Years & 28.02 & 29.81 \\
\hline Macroeconomic Indicators & Mean & Std Dev \\
\hline State Unemployment Rate (Monthly) & 5.15 & 1.22 \\
\hline \% Gain in Jobs (Quarterly) & 7.55 & 1.13 \\
\hline \% Loss in Jobs (Quarterly) & 7.12 & 0.91 \\
\hline \% Change in Average Monthly S\&P Closing (Monthly) & -0.09 & 3.50 \\
\hline \% Change in Retail Sales (Monthly) & 0.27 & 0.91 \\
\hline \% Change in House Price Index (Quarterly) & 2.35 & 5.92 \\
\hline Individual Covariates & Mean & Std. Dev \\
\hline Age & 61.70 & 7.54 \\
\hline Age squared & 3863.70 & 930.23 \\
\hline Male & 0.45 & 0.50 \\
\hline College Grad & 0.35 & 0.48 \\
\hline HS Grad & 0.41 & 0.49 \\
\hline Black & 0.16 & 0.36 \\
\hline Hispanic & 0.09 & 0.29 \\
\hline Married/Partnered & 0.75 & 0.43 \\
\hline Poor Health & 0.26 & 0.44 \\
\hline Declining Health & 0.22 & 0.42 \\
\hline Poor Mental Health & 0.14 & 0.34 \\
\hline Ln Income & 10.65 & 1.46 \\
\hline Income & 77,560 & 266,025 \\
\hline Financial Wealth & 189,702 & 956,710 \\
\hline Business Wealth & 129,625 & 992,148 \\
\hline Housing Wealth & 155,520 & 469,029 \\
\hline Rents Home & 0.17 & 0.38 \\
\hline $\mathrm{n}$ & 102,819 & \\
\hline
\end{tabular}


Table 2: Demographic and Financial Determinants of Macroeconomic Subjective Probabilities

\begin{tabular}{|c|c|c|c|c|c|c|c|c|}
\hline \multirow[b]{2}{*}{ Age } & \multicolumn{2}{|c|}{ Depression in 10} & \multicolumn{2}{|c|}{$\frac{\text { Less Generous }}{\text { Social Security }}$} & \multicolumn{2}{|c|}{$\frac{\text { Mutual Funds }}{\text { Increase }}$} & \multicolumn{2}{|c|}{$\frac{\text { Inflation in } 10}{\underline{\text { Years }}}$} \\
\hline & $\begin{array}{l}-1.188 \\
(0.189)\end{array}$ & $* *$ & $\begin{array}{l}-0.211 \\
(0.148)\end{array}$ & & $\begin{array}{l}0.961 \\
(0.218)\end{array}$ & $* *$ & $\begin{array}{c}0.531 \\
(0.324)\end{array}$ & \\
\hline Age squared & $\begin{array}{c}0.010 \\
(0.002)\end{array}$ & $* *$ & $\begin{array}{l}-0.002 \\
(0.001)\end{array}$ & & $\begin{array}{l}-0.009 \\
(0.002)\end{array}$ & $* *$ & $\begin{array}{l}-0.007 \\
(0.003)\end{array}$ & $* *$ \\
\hline Male & $\begin{array}{l}-3.823 \\
(0.324)\end{array}$ & $* *$ & $\begin{array}{l}1.222 \\
(0.395)\end{array}$ & $* *$ & $\begin{array}{l}5.897 \\
(0.471)\end{array}$ & $* *$ & $\begin{array}{l}-2.377 \\
(0.353)\end{array}$ & $* *$ \\
\hline College Grad & $\begin{array}{l}-0.797 \\
(0.63)\end{array}$ & & $\begin{array}{c}3.799 \\
(0.649)\end{array}$ & $* *$ & $\begin{array}{l}5.876 \\
(0.667)\end{array}$ & $* *$ & $\begin{array}{l}-1.640 \\
(0.649)\end{array}$ & $* *$ \\
\hline HS Grad & $\begin{array}{l}1.295 \\
(0.497)\end{array}$ & $* *$ & $\begin{array}{c}2.069 \\
(0.587)\end{array}$ & $* *$ & $\begin{array}{l}1.596 \\
(0.457)\end{array}$ & $* *$ & $\begin{array}{c}1.119 \\
(0.618)\end{array}$ & $*$ \\
\hline Black & $\begin{array}{l}2.243 \\
(0.53)\end{array}$ & $* *$ & $\begin{array}{l}-4.782 \\
(0.749)\end{array}$ & $* *$ & $\begin{array}{l}-5.044 \\
(0.708)\end{array}$ & $* *$ & $\begin{array}{l}-1.227 \\
(0.808)\end{array}$ & \\
\hline Hispanic & $\begin{array}{c}0.309 \\
(1.166)\end{array}$ & & $\begin{array}{l}-4.434 \\
(0.811)\end{array}$ & $* *$ & $\begin{array}{l}-2.607 \\
(0.852)\end{array}$ & $* *$ & $\begin{array}{c}-3.738 \\
(1.23)\end{array}$ & $* *$ \\
\hline Married/Partnered & $\begin{array}{l}-1.854 \\
(0.608)\end{array}$ & $* *$ & $\begin{array}{l}-1.068 \\
(0.478)\end{array}$ & $* *$ & $\begin{array}{l}-0.276 \\
(0.501)\end{array}$ & & $\begin{array}{l}-0.019 \\
(0.657)\end{array}$ & \\
\hline Poor Health & $\begin{array}{l}3.763 \\
(0.52)\end{array}$ & $* *$ & $\begin{array}{l}-0.027 \\
(0.43)\end{array}$ & & $\begin{array}{l}-3.693 \\
(0.411)\end{array}$ & $* *$ & $\begin{array}{l}1.015 \\
(0.487)\end{array}$ & $* *$ \\
\hline Declining Health & $\begin{array}{c}2.387 \\
(0.453)\end{array}$ & $* *$ & $\begin{array}{c}2.169 \\
(0.433)\end{array}$ & $* *$ & $\begin{array}{l}-0.901 \\
(0.326)\end{array}$ & $* *$ & $\begin{array}{c}0.904 \\
(0.401)\end{array}$ & $* *$ \\
\hline Poor Mental Health & $\begin{array}{c}4.738 \\
(0.373)\end{array}$ & $* *$ & $\begin{array}{c}1.277 \\
(0.566)\end{array}$ & $* *$ & $\begin{array}{c}-1.395 \\
(0.46)\end{array}$ & $* *$ & $\begin{array}{c}1.978 \\
(0.491)\end{array}$ & $* *$ \\
\hline Ln Income & $\begin{array}{l}-0.680 \\
(0.138)\end{array}$ & $* *$ & $\begin{array}{c}0.733 \\
(0.127)\end{array}$ & $* *$ & $\begin{array}{c}0.829 \\
(0.199)\end{array}$ & $* *$ & $\begin{array}{c}0.021 \\
(0.137)\end{array}$ & \\
\hline Financial Wealth (in $\$ 100,000$ ) & $\begin{array}{l}-0.080 \\
(0.029)\end{array}$ & $* *$ & $\begin{array}{l}-0.015 \\
(0.012)\end{array}$ & & $\begin{array}{l}0.035 \\
(0.027)\end{array}$ & & $\begin{array}{l}-0.250 \\
(0.034)\end{array}$ & $* *$ \\
\hline Business Wealth (in $\$ 100,000$ ) & $\begin{array}{l}-0.011 \\
(0.011)\end{array}$ & & $\begin{array}{l}-0.009 \\
(0.008)\end{array}$ & & $\begin{array}{l}0.005 \\
(0.008)\end{array}$ & & $\begin{array}{l}0.096 \\
(0.024)\end{array}$ & $* *$ \\
\hline Housing Wealth (in $\$ 100,000$ ) & $\begin{array}{l}-0.061 \\
(0.034)\end{array}$ & $*$ & $\begin{array}{l}0.029 \\
(0.024)\end{array}$ & & $\begin{array}{l}0.103 \\
(0.031)\end{array}$ & $* *$ & $\begin{array}{l}-0.007 \\
(0.084)\end{array}$ & \\
\hline Rents Home & $\begin{array}{l}1.176 \\
(0.657)\end{array}$ & $*$ & $\begin{array}{l}-1.066 \\
(0.396)\end{array}$ & $* *$ & $\begin{array}{l}-1.791 \\
(0.504)\end{array}$ & $* *$ & $\begin{array}{l}-0.035 \\
(0.764)\end{array}$ & \\
\hline Constant & $\begin{array}{l}86.201 \\
(6.352)\end{array}$ & $* *$ & $\begin{array}{c}72.284 \\
(4.95)\end{array}$ & $* *$ & $\begin{array}{l}11.669 \\
(7.725)\end{array}$ & & $\begin{array}{c}42.034 \\
(10.367)\end{array}$ & $* *$ \\
\hline$R-s q$ & 0.032 & & 0.028 & & 0.056 & & 0.014 & \\
\hline $\mathrm{n}$ & 59,354 & & 36,605 & & 36,960 & & 39,971 & \\
\hline
\end{tabular}

Notes: All coefficients estimated with State Fixed Effects.

** Denotes statistical significance at the $5 \%$ level, * at the $10 \%$ level. 
Fixed Effects

\begin{tabular}{|c|c|c|c|c|c|c|c|c|}
\hline \multirow[b]{2}{*}{ Age } & \multicolumn{2}{|c|}{$\frac{\text { Depression in }}{10 \text { Years }}$} & \multicolumn{2}{|c|}{$\frac{\text { Less Generous }}{\text { Social Security }}$} & \multicolumn{2}{|c|}{$\frac{\text { Mutual Funds }}{\text { Increase }}$} & \multicolumn{2}{|c|}{$\frac{\text { Inflation in } 10}{\text { Years }}$} \\
\hline & $\begin{array}{l}-1.188 \\
(0.189)\end{array}$ & $* *$ & $\begin{array}{l}-0.211 \\
(0.148)\end{array}$ & & $\begin{array}{c}0.961 \\
(0.218)\end{array}$ & $* *$ & $\begin{array}{c}0.531 \\
(0.324)\end{array}$ & \\
\hline Age squared & $\begin{array}{l}0.000 \\
(0.001)\end{array}$ & & $\begin{array}{l}-0.002 \\
(0.001)\end{array}$ & $*$ & $\begin{array}{l}-0.009 \\
(0.002)\end{array}$ & $* *$ & $\begin{array}{l}-0.005 \\
(0.003)\end{array}$ & $*$ \\
\hline Male & $\begin{array}{l}-2.821 \\
(0.336)\end{array}$ & $* *$ & $\begin{array}{l}1.282 \\
(0.406)\end{array}$ & $* *$ & $\begin{array}{l}5.850 \\
(0.47)\end{array}$ & $* *$ & $\begin{array}{l}-2.418 \\
(0.358)\end{array}$ & $* *$ \\
\hline College Grad & $\begin{array}{l}-3.003 \\
(0.619)\end{array}$ & $* *$ & $\begin{array}{l}3.640 \\
(0.662)\end{array}$ & $* *$ & $\begin{array}{l}5.911 \\
(0.657)\end{array}$ & $* *$ & $\begin{array}{l}-1.398 \\
(0.632)\end{array}$ & $* *$ \\
\hline HS Grad & $\begin{array}{l}-0.085 \\
(0.51)\end{array}$ & & $\begin{array}{l}1.970 \\
(0.577)\end{array}$ & $* *$ & $\begin{array}{l}1.612 \\
(0.453)\end{array}$ & $* *$ & $\begin{array}{l}1.283 \\
(0.607)\end{array}$ & $* *$ \\
\hline Black & $\begin{array}{l}1.922 \\
(0.527)\end{array}$ & $* *$ & $\begin{array}{l}-4.808 \\
(0.752)\end{array}$ & $* *$ & $\begin{array}{l}-5.052 \\
(0.709)\end{array}$ & $* *$ & $\begin{array}{l}-1.253 \\
(0.798)\end{array}$ & \\
\hline Hispanic & $\begin{array}{l}-1.084 \\
(1.086)\end{array}$ & & $\begin{array}{l}-4.522 \\
(0.832)\end{array}$ & $* *$ & $\begin{array}{l}-2.642 \\
(0.862)\end{array}$ & $* *$ & $\begin{array}{l}-3.706 \\
(1.242)\end{array}$ & $* *$ \\
\hline Married/Partnered & $\begin{array}{c}-1.355 \\
(0.6)\end{array}$ & $* *$ & $\begin{array}{l}-1.045 \\
(0.47)\end{array}$ & $* *$ & $\begin{array}{l}-0.255 \\
(0.498)\end{array}$ & & $\begin{array}{l}-0.125 \\
(0.652)\end{array}$ & \\
\hline Poor Health & $\begin{array}{c}3.487 \\
(0.488)\end{array}$ & $* *$ & $\begin{array}{l}-0.046 \\
(0.433)\end{array}$ & & $\begin{array}{l}-3.741 \\
(0.417)\end{array}$ & $* *$ & $\begin{array}{l}1.211 \\
(0.491)\end{array}$ & $* *$ \\
\hline Declining Health & $\begin{array}{l}1.740 \\
(0.405)\end{array}$ & $* *$ & $\begin{array}{l}2.113 \\
(0.43)\end{array}$ & $* *$ & $\begin{array}{l}-0.876 \\
(0.329)\end{array}$ & $* *$ & $\begin{array}{l}0.841 \\
(0.399)\end{array}$ & $* *$ \\
\hline Poor Mental Health & $\begin{array}{l}4.506 \\
(0.352)\end{array}$ & $* *$ & $\begin{array}{l}1.258 \\
(0.576)\end{array}$ & $* *$ & $\begin{array}{l}-1.382 \\
(0.464)\end{array}$ & $* *$ & $\begin{array}{l}2.137 \\
(0.482)\end{array}$ & $* *$ \\
\hline Ln Income & $\begin{array}{l}-0.714 \\
(0.143)\end{array}$ & $* *$ & $\begin{array}{l}0.735 \\
(0.125)\end{array}$ & $* *$ & $\begin{array}{c}0.832 \\
(0.199)\end{array}$ & $* *$ & $\begin{array}{c}0.038 \\
(0.138)\end{array}$ & \\
\hline Financial Wealth (in $\$ 100,000$ ) & $\begin{array}{l}-0.079 \\
(0.029)\end{array}$ & $* *$ & $\begin{array}{l}-0.015 \\
(0.013)\end{array}$ & & $\begin{array}{c}0.034 \\
(0.027)\end{array}$ & & $\begin{array}{l}-0.240 \\
(0.032)\end{array}$ & $* *$ \\
\hline Business Wealth (in $\$ 100,000$ ) & $\begin{array}{l}-0.007 \\
(0.011)\end{array}$ & & $\begin{array}{l}-0.008 \\
(0.008)\end{array}$ & & $\begin{array}{c}0.004 \\
(0.008)\end{array}$ & & $\begin{array}{c}0.091 \\
(0.025)\end{array}$ & $* *$ \\
\hline Housing Wealth (in $\$ 100,000$ ) & $\begin{array}{l}-0.130 \\
(0.041)\end{array}$ & $* *$ & $\begin{array}{l}0.024 \\
(0.023)\end{array}$ & & $\begin{array}{c}0.100 \\
(0.031)\end{array}$ & $* *$ & $\begin{array}{l}0.008 \\
(0.08)\end{array}$ & \\
\hline Rents Home & $\begin{array}{l}0.897 \\
(0.616)\end{array}$ & & $\begin{array}{l}-1.092 \\
(0.402)\end{array}$ & $* *$ & $\begin{array}{l}-1.787 \\
(0.502)\end{array}$ & $* *$ & $\begin{array}{l}-0.087 \\
(0.771)\end{array}$ & \\
\hline \multicolumn{9}{|c|}{ Year (1994 is ref except where noted) } \\
\hline 1996 & $\begin{array}{l}1.922 \\
(0.613)\end{array}$ & $* *$ & ref year & & & & $\begin{array}{l}1.724 \\
(0.46)\end{array}$ & $* *$ \\
\hline 1998 & $\begin{array}{l}-1.036 \\
(0.773)\end{array}$ & & $\begin{array}{l}0.103 \\
(0.701)\end{array}$ & & & & $\begin{array}{l}-3.133 \\
(0.461)\end{array}$ & $* *$ \\
\hline 2000 & & & & & & & $\begin{array}{l}-1.151 \\
(0.532)\end{array}$ & $* *$ \\
\hline 2002 & & & & & ref year & & & \\
\hline 2004 & 6.523 & $* *$ & & & 3.760 & $* *$ & & \\
\hline
\end{tabular}




\begin{tabular}{|c|c|c|c|c|c|c|c|c|}
\hline & $(0.763)$ & & & & $(0.671)$ & & & \\
\hline 2006 & $\begin{array}{c}9.131 \\
(1.027)\end{array}$ & $* *$ & $\begin{array}{c}0.731 \\
(0.587)\end{array}$ & & $\begin{array}{l}2.951 \\
(0.722)\end{array}$ & $* *$ & & \\
\hline 2008 & $\begin{array}{l}21.239 \\
(1.077)\end{array}$ & $* *$ & $\begin{array}{c}1.158 \\
(0.615)\end{array}$ & $*$ & $\begin{array}{l}1.245 \\
(0.655)\end{array}$ & $*$ & & \\
\hline Constant & $\begin{array}{l}64.742 \\
(5.805)\end{array}$ & $* *$ & $\begin{array}{l}71.225 \\
(5.105)\end{array}$ & $* *$ & $\begin{array}{c}6.381 \\
(7.342)\end{array}$ & & $\begin{array}{c}47.593 \\
(10.298)\end{array}$ & $* *$ \\
\hline R-sq & 0.085 & & 0.028 & & 0.058 & & 0.018 & \\
\hline$n$ & 59,354 & & 36,605 & & 36,960 & & 39,971 & \\
\hline
\end{tabular}

Notes: All coefficients estimated with State Fixed Effects.

** Denotes statistical significance at the $5 \%$ level, * at the $10 \%$ level. 
Table 4: Macroeconomic Determinants of Macroeconomic Subjective Probabilities

\begin{tabular}{|c|c|c|c|c|c|c|c|c|}
\hline \multirow[b]{2}{*}{ Age } & \multicolumn{2}{|c|}{$\frac{\text { Depression in }}{10 \text { Years }}$} & \multicolumn{2}{|c|}{$\frac{\text { Less Generous }}{\text { Social Security }}$} & \multicolumn{2}{|c|}{$\frac{\text { Mutual Funds }}{\text { Increase }}$} & \multicolumn{2}{|c|}{$\frac{\text { Inflation in } 10}{\text { Years }}$} \\
\hline & $\begin{array}{l}-0.322 \\
(0.169)\end{array}$ & $*$ & $\begin{array}{l}-0.160 \\
(0.149)\end{array}$ & & $\begin{array}{l}1.027 \\
(0.214)\end{array}$ & $* *$ & $\begin{array}{c}0.330 \\
(0.321)\end{array}$ & \\
\hline Age squared & $\begin{array}{l}0.000 \\
(0.001)\end{array}$ & & $\begin{array}{l}-0.002 \\
(0.001)\end{array}$ & $*$ & $\begin{array}{l}-0.009 \\
(0.002)\end{array}$ & $* *$ & $\begin{array}{l}-0.005 \\
(0.003)\end{array}$ & $*$ \\
\hline Male & $\begin{array}{l}-2.810 \\
(0.335)\end{array}$ & $* *$ & $\begin{array}{l}1.291 \\
(0.405)\end{array}$ & $* *$ & $\begin{array}{l}5.852 \\
(0.47)\end{array}$ & $* *$ & $\begin{array}{l}-2.412 \\
(0.359)\end{array}$ & $* *$ \\
\hline College Grad & $\begin{array}{l}-3.039 \\
(0.62)\end{array}$ & $* *$ & $\begin{array}{l}3.632 \\
(0.659)\end{array}$ & $* *$ & $\begin{array}{l}5.932 \\
(0.66)\end{array}$ & $* *$ & $\begin{array}{l}-1.371 \\
(0.629)\end{array}$ & $* *$ \\
\hline HS Grad & $\begin{array}{l}-0.109 \\
(0.51)\end{array}$ & & $\begin{array}{l}1.979 \\
(0.581)\end{array}$ & $* *$ & $\begin{array}{c}1.609 \\
(0.452)\end{array}$ & $* *$ & $\begin{array}{l}1.302 \\
(0.607)\end{array}$ & $* *$ \\
\hline Black & $\begin{array}{l}1.943 \\
(0.516)\end{array}$ & $* *$ & $\begin{array}{l}-4.797 \\
(0.756)\end{array}$ & $* *$ & $\begin{array}{l}-5.053 \\
(0.711)\end{array}$ & $* *$ & $\begin{array}{l}-1.290 \\
(0.802)\end{array}$ & \\
\hline Hispanic & $\begin{array}{l}-0.960 \\
(1.096)\end{array}$ & & $\begin{array}{l}-4.431 \\
(0.846)\end{array}$ & $* *$ & $\begin{array}{l}-2.623 \\
(0.858)\end{array}$ & $* *$ & $\begin{array}{l}-3.640 \\
(1.231)\end{array}$ & $* *$ \\
\hline Married/Partnered & $\begin{array}{l}-1.379 \\
(0.601)\end{array}$ & $* *$ & $\begin{array}{l}-1.064 \\
(0.468)\end{array}$ & $* *$ & $\begin{array}{l}-0.248 \\
(0.497)\end{array}$ & & $\begin{array}{l}-0.148 \\
(0.655)\end{array}$ & \\
\hline Poor Health & $\begin{array}{l}3.487 \\
(0.49)\end{array}$ & $* *$ & $\begin{array}{l}-0.021 \\
(0.431)\end{array}$ & & $\begin{array}{l}-3.746 \\
(0.42)\end{array}$ & $* *$ & $\begin{array}{l}1.179 \\
(0.493)\end{array}$ & $* *$ \\
\hline Declining Health & $\begin{array}{l}1.747 \\
(0.409)\end{array}$ & $* *$ & $\begin{array}{l}2.121 \\
(0.432)\end{array}$ & $* *$ & $\begin{array}{l}-0.853 \\
(0.332)\end{array}$ & $* *$ & $\begin{array}{c}0.856 \\
(0.404)\end{array}$ & $* *$ \\
\hline Poor Mental Health & $\begin{array}{l}4.483 \\
(0.35)\end{array}$ & $* *$ & $\begin{array}{l}1.241 \\
(0.576)\end{array}$ & $* *$ & $\begin{array}{l}-1.413 \\
(0.468)\end{array}$ & $* *$ & $\begin{array}{c}2.122 \\
(0.484)\end{array}$ & $* *$ \\
\hline Ln Income & $\begin{array}{l}-0.706 \\
(0.142)\end{array}$ & $* *$ & $\begin{array}{l}0.744 \\
(0.125)\end{array}$ & $* *$ & $\begin{array}{c}0.829 \\
(0.2)\end{array}$ & $* *$ & $\begin{array}{c}0.033 \\
(0.139)\end{array}$ & \\
\hline Financial Wealth (in $\$ 100,000$ ) & $\begin{array}{l}-0.079 \\
(0.029)\end{array}$ & $* *$ & $\begin{array}{l}-0.015 \\
(0.012)\end{array}$ & & $\begin{array}{l}0.034 \\
(0.027)\end{array}$ & & $\begin{array}{l}-0.240 \\
(0.032)\end{array}$ & $* *$ \\
\hline Business Wealth (in $\$ 100,000$ ) & $\begin{array}{l}-0.007 \\
(0.011)\end{array}$ & & $\begin{array}{l}-0.009 \\
(0.009)\end{array}$ & & $\begin{array}{l}0.004 \\
(0.008)\end{array}$ & & $\begin{array}{c}0.091 \\
(0.024)\end{array}$ & $* *$ \\
\hline Housing Wealth (in $\$ 100,000$ ) & $\begin{array}{l}-0.129 \\
(0.041)\end{array}$ & $* *$ & $\begin{array}{l}0.025 \\
(0.022)\end{array}$ & & $\begin{array}{l}0.100 \\
(0.031)\end{array}$ & $* *$ & $\begin{array}{c}0.008 \\
(0.081)\end{array}$ & \\
\hline Rents Home & $\begin{array}{l}0.854 \\
(0.614)\end{array}$ & & $\begin{array}{l}-1.100 \\
(0.405)\end{array}$ & $* *$ & $\begin{array}{l}-1.797 \\
(0.505)\end{array}$ & $* *$ & $\begin{array}{l}-0.079 \\
(0.773)\end{array}$ & \\
\hline \multicolumn{9}{|c|}{ Year (1994 is ref except where noted) } \\
\hline 1996 & $\begin{array}{l}3.024 \\
(0.643)\end{array}$ & $* *$ & ref year & & & & $\begin{array}{c}2.205 \\
(0.636)\end{array}$ & $* *$ \\
\hline 1998 & $\begin{array}{l}1.350 \\
(0.891)\end{array}$ & & $\begin{array}{l}0.526 \\
(0.735)\end{array}$ & & & & $\begin{array}{l}-2.224 \\
(0.918)\end{array}$ & $* *$ \\
\hline 2000 & & & & & & & $\begin{array}{l}-0.079 \\
(1.022)\end{array}$ & \\
\hline 2002 & & & & & ref year & & & \\
\hline 2004 & 6.503 & $* *$ & & & 4.085 & $* *$ & & \\
\hline
\end{tabular}




\begin{tabular}{|c|c|c|c|c|c|c|c|c|}
\hline & $(0.789)$ & & & & $(0.579)$ & & & \\
\hline 2006 & $\begin{array}{l}10.040 \\
(1.083)\end{array}$ & $* *$ & $\begin{array}{l}1.046 \\
(0.75)\end{array}$ & & $\begin{array}{c}2.814 \\
(0.711)\end{array}$ & $* *$ & & \\
\hline 2008 & $\begin{array}{l}21.484 \\
(1.106)\end{array}$ & $* *$ & $\begin{array}{l}1.817 \\
(0.949)\end{array}$ & $*$ & $\begin{array}{l}1.875 \\
(0.626)\end{array}$ & $* *$ & & \\
\hline Unemployment Rate & $\begin{array}{l}1.352 \\
(0.41)\end{array}$ & $* *$ & $\begin{array}{l}0.529 \\
(0.299)\end{array}$ & $*$ & $\begin{array}{l}-0.651 \\
(0.404)\end{array}$ & & $\begin{array}{c}0.471 \\
(0.435)\end{array}$ & \\
\hline \% Change Job Gains & $\begin{array}{l}-0.349 \\
(0.352)\end{array}$ & & $\begin{array}{c}0.533 \\
(0.484)\end{array}$ & & $\begin{array}{l}0.082 \\
(0.308)\end{array}$ & & $\begin{array}{c}0.413 \\
(0.223)\end{array}$ & $*$ \\
\hline \% Change Job Losses & $\begin{array}{l}-0.247 \\
(0.537)\end{array}$ & & $\begin{array}{l}-0.580 \\
(0.454)\end{array}$ & & $\begin{array}{c}0.158 \\
(0.476)\end{array}$ & & $\begin{array}{l}-0.230 \\
(0.402)\end{array}$ & \\
\hline \% Change S\&P 500 & $\begin{array}{l}-0.116 \\
(0.050)\end{array}$ & $* *$ & $\begin{array}{l}-0.085 \\
(0.053)\end{array}$ & & $\begin{array}{l}-0.098 \\
(0.048)\end{array}$ & $* *$ & $\begin{array}{l}-0.078 \\
(0.061)\end{array}$ & \\
\hline \% Change Retail & $\begin{array}{l}-0.059 \\
(0.180)\end{array}$ & & $\begin{array}{l}0.362 \\
(0.196)\end{array}$ & $*$ & $\begin{array}{c}0.073 \\
(0.131)\end{array}$ & & $\begin{array}{c}0.081 \\
(0.186)\end{array}$ & \\
\hline \% Change HPI & $\begin{array}{c}0.062 \\
(0.035)\end{array}$ & $*$ & $\begin{array}{c}0.029 \\
(0.037)\end{array}$ & & $\begin{array}{c}0.034 \\
(0.025)\end{array}$ & & $\begin{array}{c}0.030 \\
(0.092)\end{array}$ & \\
\hline Constant & $\begin{array}{l}61.513 \\
(8.036)\end{array}$ & $* *$ & $\begin{array}{l}67.925 \\
(7.125)\end{array}$ & $* *$ & $\begin{array}{c}7.972 \\
(8.016)\end{array}$ & & $\begin{array}{l}43.226 \\
(10.931)\end{array}$ & $* *$ \\
\hline R-sq & 0.084 & & 0.028 & & 0.058 & & 0.019 & \\
\hline $\mathrm{n}$ & 59,245 & & 36,537 & & 36,924 & & 39,870 & \\
\hline
\end{tabular}

Notes: All coefficients estimated with State Fixed Effects.

** Denotes statistical significance at the $5 \%$ level, * at the $10 \%$ level. 
Table 5: Macroeconomic Determinants of Macroeconomic Subjective Probabilities, Interacted with Education

\begin{tabular}{|c|c|c|c|c|c|c|c|c|}
\hline \multirow[b]{2}{*}{ Unemployment Rate } & \multicolumn{2}{|c|}{$\frac{\text { Depression in } 10}{\underline{\text { Years }}}$} & \multicolumn{2}{|c|}{$\frac{\text { Less Generous }}{\text { Social Security }}$} & \multicolumn{2}{|c|}{$\frac{\text { Mutual Funds }}{\text { Increase }}$} & \multicolumn{2}{|c|}{$\frac{\text { Inflation in } 10}{\text { Years }}$} \\
\hline & $\begin{array}{c}0.999 \\
(0.415)\end{array}$ & $* *$ & $\begin{array}{c}0.432 \\
(0.341)\end{array}$ & & $\begin{array}{l}-0.560 \\
(0.471)\end{array}$ & & $\begin{array}{l}0.137 \\
(0.412)\end{array}$ & \\
\hline * College Grad & $\begin{array}{c}0.982 \\
(0.328)\end{array}$ & $* *$ & $\begin{array}{c}0.231 \\
(0.321)\end{array}$ & & $\begin{array}{l}-0.156 \\
(0.368)\end{array}$ & & $\begin{array}{l}0.933 \\
(0.351)\end{array}$ & $* *$ \\
\hline \% Change Job Gains & $\begin{array}{l}-0.268 \\
(0.416)\end{array}$ & & $\begin{array}{c}0.606 \\
(0.457)\end{array}$ & & $\begin{array}{c}0.114 \\
(0.353)\end{array}$ & & $\begin{array}{l}0.422 \\
(0.323)\end{array}$ & \\
\hline * College Grad & $\begin{array}{l}-0.205 \\
(0.528)\end{array}$ & & $\begin{array}{l}-0.215 \\
(0.518)\end{array}$ & & $\begin{array}{l}-0.141 \\
(0.564)\end{array}$ & & $\begin{array}{l}-0.031 \\
(0.614)\end{array}$ & \\
\hline \% Change Job Losses & $\begin{array}{l}-0.645 \\
(0.494)\end{array}$ & & $\begin{array}{l}-1.008 \\
(0.459)\end{array}$ & $* *$ & $\begin{array}{c}0.423 \\
(0.496)\end{array}$ & & $\begin{array}{l}-0.093 \\
(0.569)\end{array}$ & \\
\hline * College Grad & $\begin{array}{l}1.052 \\
(0.543)\end{array}$ & $*$ & $\begin{array}{c}1.146 \\
(0.677)\end{array}$ & $*$ & $\begin{array}{l}-0.734 \\
(0.587)\end{array}$ & & $\begin{array}{l}-0.469 \\
(0.729)\end{array}$ & \\
\hline \% Change S\&P 500 & $\begin{array}{l}-0.087 \\
(0.062)\end{array}$ & & $\begin{array}{l}-0.129 \\
(0.051)\end{array}$ & $* *$ & $\begin{array}{l}-0.065 \\
(0.051)\end{array}$ & & $\begin{array}{l}-0.079 \\
(0.078)\end{array}$ & \\
\hline * College Grad & $\begin{array}{l}-0.068 \\
(0.076)\end{array}$ & & $\begin{array}{c}0.112 \\
(0.093)\end{array}$ & & $\begin{array}{c}-0.090 \\
(0.06314)\end{array}$ & & $\begin{array}{l}0.004 \\
(0.099)\end{array}$ & \\
\hline$\%$ Change Retail & $\begin{array}{c}0.189 \\
(0.206)\end{array}$ & & $\begin{array}{l}0.210 \\
(0.242)\end{array}$ & & $\begin{array}{l}-0.278 \\
(0.181)\end{array}$ & & $\begin{array}{l}0.101 \\
(0.281)\end{array}$ & \\
\hline * College Grad & $\begin{array}{l}-0.634 \\
(0.340)\end{array}$ & $*$ & $\begin{array}{c}0.356 \\
(0.422)\end{array}$ & & $\begin{array}{l}0.835 \\
(0.265)\end{array}$ & $* *$ & $\begin{array}{l}-0.058 \\
(0.489)\end{array}$ & \\
\hline \% Change HPI & $\begin{array}{c}-0.003 \\
(0.03833)\end{array}$ & & $\begin{array}{c}-0.021 \\
(0.04423)\end{array}$ & & $\begin{array}{l}-0.005 \\
(0.034)\end{array}$ & & $\begin{array}{c}0.105 \\
(0.133)\end{array}$ & \\
\hline * College Grad & $\begin{array}{l}0.160 \\
(0.039)\end{array}$ & $* *$ & $\begin{array}{c}0.121 \\
(0.059)\end{array}$ & $* *$ & $\begin{array}{l}0.080 \\
(0.037)\end{array}$ & $* *$ & $\begin{array}{l}-0.165 \\
(0.161)\end{array}$ & \\
\hline Constant & $\begin{array}{l}65.289 \\
(8.24)\end{array}$ & $* *$ & $\begin{array}{l}70.739 \\
(7.502)\end{array}$ & $* *$ & $\begin{array}{l}5.399 \\
(7.701)\end{array}$ & & $\begin{array}{l}43.739 \\
(11.353)\end{array}$ & $* *$ \\
\hline$R-s q$ & 0.085 & & 0.029 & & 0.059 & & 0.019 & \\
\hline$n$ & 59,245 & & 36,537 & & 36,924 & & 39,870 & \\
\hline
\end{tabular}

Notes: All coefficients estimated with State Fixed Effects.

** Denotes statistical significance at the $5 \%$ level, * at the $10 \%$ level.

Regressions control for all other covariates listed in Table 2. 
Table 6: Demographic and Financial Determinants of Personal and Financial Subjective Probabilities

\begin{tabular}{|c|c|c|c|c|c|c|c|c|}
\hline \multirow[b]{3}{*}{ Age } & \multicolumn{6}{|c|}{ Work at Age } & \multirow{2}{*}{\multicolumn{2}{|c|}{ Exhaust Savings }} \\
\hline & \multicolumn{2}{|l|}{62} & \multicolumn{2}{|c|}{ Work at Age 65} & \multicolumn{2}{|c|}{ Leave Bequest } & & \\
\hline & $\begin{array}{l}-2.412 \\
(0.716)\end{array}$ & $* *$ & $\begin{array}{l}-2.009 \\
(0.624)\end{array}$ & $* *$ & $\begin{array}{c}0.818 \\
(0.185)\end{array}$ & $* *$ & $\begin{array}{l}-0.066 \\
(0.212)\end{array}$ & \\
\hline Age squared & $\begin{array}{l}0.026 \\
(0.007)\end{array}$ & $* *$ & $\begin{array}{l}0.020 \\
(0.006)\end{array}$ & $* *$ & $\begin{array}{l}-0.006 \\
(0.002)\end{array}$ & $* *$ & $\begin{array}{c}0.001 \\
(0.002)\end{array}$ & \\
\hline Male & $\begin{array}{l}8.607 \\
(0.683)\end{array}$ & $* *$ & $\begin{array}{c}7.177 \\
(0.471)\end{array}$ & $* *$ & $\begin{array}{l}4.711 \\
(0.327)\end{array}$ & $* *$ & $\begin{array}{l}-2.941 \\
(0.396)\end{array}$ & $* *$ \\
\hline College Grad & $\begin{array}{l}7.608 \\
(0.813)\end{array}$ & $* *$ & $\begin{array}{c}6.751 \\
(0.728)\end{array}$ & $* *$ & $\begin{array}{l}18.437 \\
(0.731)\end{array}$ & $* *$ & $\begin{array}{l}-5.578 \\
(0.647)\end{array}$ & $* *$ \\
\hline HS Grad & $\begin{array}{l}3.045 \\
(0.63)\end{array}$ & $* *$ & $\begin{array}{c}2.044 \\
(0.559)\end{array}$ & $* *$ & $\begin{array}{l}11.821 \\
(0.597)\end{array}$ & $* *$ & $\begin{array}{l}-0.105 \\
(0.592)\end{array}$ & \\
\hline Black & $\begin{array}{l}-9.410 \\
(1.125)\end{array}$ & $* *$ & $\begin{array}{l}-7.691 \\
(0.811)\end{array}$ & $* *$ & $\begin{array}{c}-10.603 \\
(0.828)\end{array}$ & $* *$ & $\begin{array}{c}2.186 \\
(0.674)\end{array}$ & $* *$ \\
\hline Hispanic & $\begin{array}{l}-2.064 \\
(0.964)\end{array}$ & $* *$ & $\begin{array}{l}-2.020 \\
(0.84)\end{array}$ & $* *$ & $\begin{array}{l}-5.696 \\
(0.808)\end{array}$ & $* *$ & $\begin{array}{c}0.446 \\
(1.971)\end{array}$ & \\
\hline Married/Partnered & $\begin{array}{l}-7.773 \\
(0.79)\end{array}$ & $* *$ & $\begin{array}{l}-6.726 \\
(0.697)\end{array}$ & $* *$ & $\begin{array}{l}-0.334 \\
(0.548)\end{array}$ & & $\begin{array}{l}1.375 \\
(0.491)\end{array}$ & $* *$ \\
\hline Poor Health & $\begin{array}{l}-9.034 \\
(0.744)\end{array}$ & $* *$ & $\begin{array}{l}-6.540 \\
(0.461)\end{array}$ & $* *$ & $\begin{array}{l}-8.992 \\
(0.421)\end{array}$ & $* *$ & $\begin{array}{l}5.597 \\
(0.463)\end{array}$ & $* *$ \\
\hline Declining Health & $\begin{array}{l}-3.041 \\
(0.765)\end{array}$ & $* *$ & $\begin{array}{l}-2.523 \\
(0.714)\end{array}$ & $* *$ & $\begin{array}{l}-0.937 \\
(0.296)\end{array}$ & $* *$ & $\begin{array}{c}1.698 \\
(0.507)\end{array}$ & $* *$ \\
\hline Poor Mental Health & $\begin{array}{l}-2.591 \\
(0.89)\end{array}$ & $* *$ & $\begin{array}{l}-0.528 \\
(0.708)\end{array}$ & & $\begin{array}{l}-5.391 \\
(0.535)\end{array}$ & $* *$ & $\begin{array}{l}5.123 \\
(0.566)\end{array}$ & $* *$ \\
\hline Ln Income & $\begin{array}{c}0.739 \\
(0.168)\end{array}$ & $* *$ & $\begin{array}{l}0.210 \\
(0.128)\end{array}$ & & $\begin{array}{c}3.798 \\
(0.259)\end{array}$ & $* *$ & $\begin{array}{l}-1.632 \\
(0.223)\end{array}$ & $* *$ \\
\hline Financial Wealth (in $\$ 100,000$ ) & $\begin{array}{l}-0.413 \\
(0.121)\end{array}$ & $* *$ & $\begin{array}{l}-0.174 \\
(0.065)\end{array}$ & $* *$ & $\begin{array}{c}0.123 \\
(0.045)\end{array}$ & $* *$ & $\begin{array}{c}-0.0899 \\
(0.029)\end{array}$ & $* *$ \\
\hline Business Wealth (in $\$ 100,000$ ) & $\begin{array}{l}0.0316 \\
(0.047)\end{array}$ & & $\begin{array}{l}0.0494 \\
(0.038)\end{array}$ & & $\begin{array}{l}0.0438 \\
(0.021)\end{array}$ & $* *$ & $\begin{array}{c}-0.0168 \\
(0.013)\end{array}$ & \\
\hline Housing Wealth (in $\$ 100,000$ ) & $\begin{array}{c}-0.098 \\
(0.09)\end{array}$ & & $\begin{array}{l}0.0334 \\
(0.057)\end{array}$ & & $\begin{array}{c}0.324 \\
(0.079)\end{array}$ & $* *$ & $\begin{array}{l}-0.164 \\
(0.045)\end{array}$ & $* *$ \\
\hline Rents Home & $\begin{array}{l}5.995 \\
(0.85)\end{array}$ & $* *$ & $\begin{array}{l}6.921 \\
(0.735)\end{array}$ & $* *$ & $\begin{array}{c}-30.236 \\
(0.713)\end{array}$ & $* *$ & $\begin{array}{c}2.111 \\
(0.785)\end{array}$ & $* *$ \\
\hline Constant & $\begin{array}{c}91.205 \\
(19.335)\end{array}$ & $* *$ & $\begin{array}{c}73.882 \\
(18.042)\end{array}$ & $* *$ & $\begin{array}{l}-2.311 \\
(7.101)\end{array}$ & & $\begin{array}{l}46.300 \\
(7.252)\end{array}$ & $* *$ \\
\hline R-sq & 0.054 & & 0.046 & & 0.316 & & 0.065 & \\
\hline $\mathrm{n}$ & 33,825 & & 40,090 & & 92,362 & & 37,635 & \\
\hline
\end{tabular}

Notes: All coefficients estimated with State Fixed Effects.

** Denotes statistical significance at the $5 \%$ level, * at the $10 \%$ level. 
Table 7: Demographic and Financial Determinants of Personal and Financial Subjective Probabilities, With Year Fixed Effects

\begin{tabular}{|c|c|c|c|c|c|c|c|c|}
\hline & \multicolumn{2}{|c|}{ Work at Age } & & & & & \multicolumn{2}{|c|}{ Exhaust } \\
\hline & $\underline{62}$ & & \multicolumn{2}{|c|}{ Work at Age 65} & \multicolumn{2}{|c|}{ Leave Bequest } & \multicolumn{2}{|c|}{ Savings } \\
\hline Age & $\begin{array}{l}-2.184 \\
(0.716)\end{array}$ & $* *$ & $\begin{array}{l}-1.527 \\
(0.617)\end{array}$ & $* *$ & $\begin{array}{c}0.838 \\
(0.177)\end{array}$ & $* *$ & $\begin{array}{l}-0.094 \\
(0.212)\end{array}$ & \\
\hline Age squared & $\begin{array}{l}0.024 \\
(0.007)\end{array}$ & $* *$ & $\begin{array}{l}0.015 \\
(0.006)\end{array}$ & $* *$ & $\begin{array}{l}-0.006 \\
(0.001)\end{array}$ & $* *$ & $\begin{array}{l}0.001 \\
(0.002)\end{array}$ & \\
\hline Male & $\begin{array}{l}8.713 \\
(0.677)\end{array}$ & $* *$ & $\begin{array}{l}7.355 \\
(0.466)\end{array}$ & $* *$ & $\begin{array}{l}4.775 \\
(0.327)\end{array}$ & $* *$ & $\begin{array}{l}-2.997 \\
(0.393)\end{array}$ & $* *$ \\
\hline College Grad & $\begin{array}{l}6.353 \\
(0.803)\end{array}$ & $* *$ & $\begin{array}{l}5.241 \\
(0.679)\end{array}$ & $* *$ & $\begin{array}{c}18.331 \\
(0.72)\end{array}$ & $* *$ & $\begin{array}{l}-5.457 \\
(0.648)\end{array}$ & $* *$ \\
\hline HS Grad & $\begin{array}{l}2.283 \\
(0.607)\end{array}$ & $* *$ & $\begin{array}{c}1.101 \\
(0.552)\end{array}$ & $*$ & $\begin{array}{l}11.753 \\
(0.598)\end{array}$ & $* *$ & $\begin{array}{l}-0.031 \\
(0.595)\end{array}$ & \\
\hline Black & $\begin{array}{l}-9.511 \\
(1.14)\end{array}$ & $* *$ & $\begin{array}{l}-7.821 \\
(0.797)\end{array}$ & $* *$ & $\begin{array}{c}-10.605 \\
(0.833)\end{array}$ & $* *$ & $\begin{array}{c}2.194 \\
(0.676)\end{array}$ & $* *$ \\
\hline Hispanic & $\begin{array}{l}-2.798 \\
(1.002)\end{array}$ & $* *$ & $\begin{array}{l}-2.890 \\
(0.831)\end{array}$ & $* *$ & $\begin{array}{l}-5.744 \\
(0.797)\end{array}$ & $* *$ & $\begin{array}{c}0.496 \\
(1.976)\end{array}$ & \\
\hline Married/Partnered & $\begin{array}{l}-7.589 \\
(0.782)\end{array}$ & $* *$ & $\begin{array}{l}-6.602 \\
(0.684)\end{array}$ & $* *$ & $\begin{array}{l}-0.307 \\
(0.556)\end{array}$ & & $\begin{array}{l}1.362 \\
(0.49)\end{array}$ & $* *$ \\
\hline Poor Health & $\begin{array}{l}-9.269 \\
(0.737)\end{array}$ & $* *$ & $\begin{array}{l}-6.893 \\
(0.483)\end{array}$ & $* *$ & $\begin{array}{l}-8.987 \\
(0.422)\end{array}$ & $* *$ & $\begin{array}{l}5.565 \\
(0.462)\end{array}$ & $* *$ \\
\hline Declining Health & $\begin{array}{l}-2.849 \\
(0.758)\end{array}$ & $* *$ & $\begin{array}{l}-2.517 \\
(0.695)\end{array}$ & $* *$ & $\begin{array}{l}-0.971 \\
(0.292)\end{array}$ & $* *$ & $\begin{array}{c}1.783 \\
(0.499)\end{array}$ & $* *$ \\
\hline Poor Mental Health & $\begin{array}{l}-2.592 \\
(0.865)\end{array}$ & $* *$ & $\begin{array}{l}-0.607 \\
(0.69)\end{array}$ & & $\begin{array}{l}-5.425 \\
(0.535)\end{array}$ & $* *$ & $\begin{array}{l}5.125 \\
(0.565)\end{array}$ & $* *$ \\
\hline Ln Income & $\begin{array}{l}0.635 \\
(0.164)\end{array}$ & $* *$ & $\begin{array}{c}0.149 \\
(0.123)\end{array}$ & & $\begin{array}{l}3.787 \\
(0.26)\end{array}$ & $* *$ & $\begin{array}{l}-1.631 \\
(0.224)\end{array}$ & $* *$ \\
\hline Financial Wealth (in $\$ 100,000$ ) & $\begin{array}{l}-0.42 \\
(0.12)\end{array}$ & $* *$ & $\begin{array}{l}-0.179 \\
(0.065)\end{array}$ & $* *$ & $\begin{array}{c}0.123 \\
(0.044)\end{array}$ & $* *$ & $\begin{array}{c}-0.0904 \\
(0.03)\end{array}$ & $* *$ \\
\hline Business Wealth (in $\$ 100,000$ ) & $\begin{array}{c}0.039 \\
(0.049)\end{array}$ & & $\begin{array}{l}0.055 \\
(0.04)\end{array}$ & & $\begin{array}{c}0.044 \\
(0.021)\end{array}$ & $* *$ & $\begin{array}{l}-0.016 \\
(0.013)\end{array}$ & \\
\hline Housing Wealth (in $\$ 100,000$ ) & $\begin{array}{l}-0.118 \\
(0.096)\end{array}$ & & $\begin{array}{l}0.001 \\
(0.064)\end{array}$ & & $\begin{array}{c}0.322 \\
(0.079)\end{array}$ & $* *$ & $\begin{array}{l}-0.161 \\
(0.045)\end{array}$ & $* *$ \\
\hline Rents Home & $\begin{array}{c}6.085 \\
(0.821)\end{array}$ & $* *$ & $\begin{array}{c}6.965 \\
(0.726)\end{array}$ & $* *$ & $\begin{array}{c}-30.229 \\
(0.713)\end{array}$ & $* *$ & $\begin{array}{c}2.150 \\
(0.783)\end{array}$ & $* *$ \\
\hline \multicolumn{9}{|c|}{ Year (1994 is ref except where noted) } \\
\hline 1996 & $\begin{array}{l}3.204 \\
(0.517)\end{array}$ & $* *$ & $\begin{array}{c}3.342 \\
(0.463)\end{array}$ & $* *$ & $\begin{array}{c}1.444 \\
(0.797)\end{array}$ & $*$ & & \\
\hline 1998 & $\begin{array}{l}4.686 \\
(0.608)\end{array}$ & $* *$ & $\begin{array}{c}3.837 \\
(0.431)\end{array}$ & $* *$ & $\begin{array}{c}1.978 \\
(0.588)\end{array}$ & $* *$ & & \\
\hline 2000 & $\begin{array}{c}7.614 \\
(0.571)\end{array}$ & $* *$ & $\begin{array}{c}6.953 \\
(0.641)\end{array}$ & $* *$ & $\begin{array}{c}2.609 \\
(0.676)\end{array}$ & $* *$ & & \\
\hline 2002 & $\begin{array}{l}6.995 \\
(1.027)\end{array}$ & $* *$ & $\begin{array}{c}7.143 \\
(0.865)\end{array}$ & $* *$ & $\begin{array}{c}1.588 \\
(0.624)\end{array}$ & $* *$ & & \\
\hline 2004 & 9.033 & $* *$ & 10.200 & ** & 0.138 & & ref year & \\
\hline
\end{tabular}




\begin{tabular}{|c|c|c|c|c|c|c|c|c|}
\hline & $(0.801)$ & & $(0.832)$ & & (0.898) & & & \\
\hline 2006 & $\begin{array}{c}1.546 \\
(1.191)\end{array}$ & & $\begin{array}{c}3.838 \\
(0.879)\end{array}$ & $* *$ & $\begin{array}{c}1.973 \\
(0.986)\end{array}$ & $*$ & $\begin{array}{l}-1.998 \\
(0.331)\end{array}$ & $* *$ \\
\hline 2008 & $\begin{array}{l}11.395 \\
(1.229)\end{array}$ & $* *$ & $\begin{array}{l}12.194 \\
(0.904)\end{array}$ & $* *$ & $\begin{array}{c}2.542 \\
(0.642)\end{array}$ & $* *$ & $\begin{array}{l}-2.643 \\
(0.368)\end{array}$ & $* *$ \\
\hline Constant & $\begin{array}{c}82.784 \\
(19.121)\end{array}$ & $* *$ & $\begin{array}{c}58.882 \\
(17.659)\end{array}$ & $* *$ & $\begin{array}{l}-3.591 \\
(6.881)\end{array}$ & & $\begin{array}{l}47.722 \\
(7.254)\end{array}$ & $* *$ \\
\hline R-sq & 0.063 & & 0.059 & & 0.316 & & 0.067 & \\
\hline $\mathrm{n}$ & 33,825 & & 40,090 & & 92,362 & & 37,635 & \\
\hline
\end{tabular}

Notes: All coefficients estimated with State Fixed Effects.

** Denotes statistical significance at the $5 \%$ level, * at the $10 \%$ level. 
Table 8: Macroeconomic Determinants of Personal and Financial Subjective Probabilities

\begin{tabular}{|c|c|c|c|c|c|c|c|c|}
\hline \multirow[b]{2}{*}{ Age } & \multicolumn{2}{|c|}{ Work at Age 62} & \multicolumn{2}{|c|}{ Work at Age 65} & \multicolumn{2}{|c|}{ Leave Bequest } & \multicolumn{2}{|c|}{ Exhaust Savings } \\
\hline & $\begin{array}{l}-2.222 \\
(0.718)\end{array}$ & $* *$ & $\begin{array}{l}-1.537 \\
(0.618)\end{array}$ & $* *$ & $\begin{array}{c}0.857 \\
(0.178)\end{array}$ & $* *$ & $\begin{array}{l}-0.078 \\
(0.207)\end{array}$ & \\
\hline Age squared & $\begin{array}{c}0.025 \\
(0.007)\end{array}$ & $* *$ & $\begin{array}{c}0.016 \\
(0.006)\end{array}$ & $* *$ & $\begin{array}{l}-0.007 \\
(0.001)\end{array}$ & $* *$ & $\begin{array}{c}0.001 \\
(0.002)\end{array}$ & \\
\hline Male & $\begin{array}{l}8.715 \\
(0.68)\end{array}$ & $* *$ & $\begin{array}{c}7.349 \\
(0.469)\end{array}$ & $* *$ & $\begin{array}{c}4.758 \\
(0.328)\end{array}$ & $* *$ & $\begin{array}{l}-3.031 \\
(0.393)\end{array}$ & $* *$ \\
\hline College Grad & $\begin{array}{c}6.408 \\
(0.802)\end{array}$ & $* *$ & $\begin{array}{c}5.252 \\
(0.683)\end{array}$ & $* *$ & $\begin{array}{l}18.336 \\
(0.722)\end{array}$ & $* *$ & $\begin{array}{l}-5.432 \\
(0.651)\end{array}$ & $* *$ \\
\hline HS Grad & $\begin{array}{c}2.333 \\
(0.609)\end{array}$ & $* *$ & $\begin{array}{c}1.126 \\
(0.551)\end{array}$ & $* *$ & $\begin{array}{c}11.753 \\
(0.6)\end{array}$ & $* *$ & $\begin{array}{l}-0.022 \\
(0.598)\end{array}$ & \\
\hline Black & $\begin{array}{l}-9.561 \\
(1.142)\end{array}$ & $* *$ & $\begin{array}{l}-7.822 \\
(0.796)\end{array}$ & $* *$ & $\begin{array}{c}-10.608 \\
(0.837)\end{array}$ & $* *$ & $\begin{array}{c}2.178 \\
(0.678)\end{array}$ & $* *$ \\
\hline Hispanic & $\begin{array}{l}-2.770 \\
(0.997)\end{array}$ & $* *$ & $\begin{array}{l}-2.826 \\
(0.836)\end{array}$ & $* *$ & $\begin{array}{l}-5.729 \\
(0.791)\end{array}$ & $* *$ & $\begin{array}{c}0.398 \\
(2)\end{array}$ & \\
\hline Married/Partnered & $\begin{array}{l}-7.645 \\
(0.783)\end{array}$ & $* *$ & $\begin{array}{l}-6.646 \\
(0.682)\end{array}$ & $* *$ & $\begin{array}{l}-0.282 \\
(0.555)\end{array}$ & & $\begin{array}{c}1.361 \\
(0.493)\end{array}$ & $* *$ \\
\hline Poor Health & $\begin{array}{l}-9.222 \\
(0.736)\end{array}$ & $* *$ & $\begin{array}{l}-6.862 \\
(0.482)\end{array}$ & $* *$ & $\begin{array}{l}-8.974 \\
(0.423)\end{array}$ & $* *$ & $\begin{array}{c}5.608 \\
(0.464)\end{array}$ & $* *$ \\
\hline Declining Health & $\begin{array}{l}-2.850 \\
(0.761)\end{array}$ & $* *$ & $\begin{array}{c}-2.525 \\
(0.7)\end{array}$ & $* *$ & $\begin{array}{l}-0.962 \\
(0.295)\end{array}$ & $* *$ & $\begin{array}{c}1.720 \\
(0.494)\end{array}$ & $* *$ \\
\hline Poor Mental Health & $\begin{array}{l}-2.576 \\
(0.875)\end{array}$ & $* *$ & $\begin{array}{l}-0.631 \\
(0.695)\end{array}$ & & $\begin{array}{l}-5.455 \\
(0.539)\end{array}$ & $* *$ & $\begin{array}{c}5.136 \\
(0.569)\end{array}$ & $* *$ \\
\hline Ln Income & $\begin{array}{c}0.638 \\
(0.164)\end{array}$ & $* *$ & $\begin{array}{c}0.153 \\
(0.124)\end{array}$ & & $\begin{array}{c}3.781 \\
(0.261)\end{array}$ & $* *$ & $\begin{array}{l}-1.612 \\
(0.222)\end{array}$ & $* *$ \\
\hline Financial Wealth (in $\$ 100,000$ ) & $\begin{array}{c}-0.419 \\
(0.12)\end{array}$ & $* *$ & $\begin{array}{l}-0.181 \\
(0.066)\end{array}$ & $* *$ & $\begin{array}{c}0.124 \\
(0.045)\end{array}$ & $* *$ & $\begin{array}{l}-0.09 \\
(0.03)\end{array}$ & $* *$ \\
\hline Business Wealth (in $\$ 100,000$ ) & $\begin{array}{l}0.0388 \\
(0.049)\end{array}$ & & $\begin{array}{c}0.0551 \\
(0.04)\end{array}$ & & $\begin{array}{l}0.0437 \\
(0.021)\end{array}$ & $* *$ & $\begin{array}{c}-0.0165 \\
(0.013)\end{array}$ & \\
\hline Housing Wealth (in $\$ 100,000$ ) & $\begin{array}{l}-0.118 \\
(0.096)\end{array}$ & & $\begin{array}{c}0.00025 \\
(0.064)\end{array}$ & & $\begin{array}{c}0.32 \\
(0.079)\end{array}$ & $* *$ & $\begin{array}{l}-0.161 \\
(0.045)\end{array}$ & $* *$ \\
\hline Rents Home & $\begin{array}{c}6.015 \\
(0.831)\end{array}$ & $* *$ & $\begin{array}{c}6.941 \\
(0.732)\end{array}$ & $* *$ & $\begin{array}{c}-30.232 \\
(0.716)\end{array}$ & $* *$ & $\begin{array}{c}2.182 \\
(0.786)\end{array}$ & $* *$ \\
\hline \multicolumn{9}{|c|}{ Year (1994 is ref except where noted) } \\
\hline 1996 & $\begin{array}{c}3.615 \\
(0.619)\end{array}$ & $* *$ & $\begin{array}{c}3.951 \\
(0.682)\end{array}$ & $* *$ & $\begin{array}{c}1.326 \\
(0.728)\end{array}$ & $*$ & & \\
\hline 1998 & $\begin{array}{c}5.577 \\
(0.893)\end{array}$ & $* *$ & $\begin{array}{l}5.446 \\
(0.83)\end{array}$ & $* *$ & $\begin{array}{c}1.794 \\
(0.798)\end{array}$ & $* *$ & & \\
\hline 2000 & $\begin{array}{c}8.378 \\
(0.975)\end{array}$ & $* *$ & $\begin{array}{c}8.459 \\
(1.008)\end{array}$ & $* *$ & $\begin{array}{c}2.335 \\
(0.853)\end{array}$ & $* *$ & & \\
\hline 2002 & $\begin{array}{c}7.073 \\
(1.079)\end{array}$ & $* *$ & $\begin{array}{c}6.824 \\
(0.942)\end{array}$ & $* *$ & $\begin{array}{c}0.909 \\
(0.689)\end{array}$ & & & \\
\hline 2004 & $\begin{array}{c}9.045 \\
(0.885)\end{array}$ & $* *$ & $\begin{array}{l}10.196 \\
(0.867)\end{array}$ & $* *$ & $\begin{array}{l}-0.741 \\
(0.853)\end{array}$ & & ref year & \\
\hline
\end{tabular}




\begin{tabular}{|c|c|c|c|c|c|c|c|c|}
\hline 2006 & $\begin{array}{c}1.712 \\
(1.256)\end{array}$ & & $\begin{array}{c}4.203 \\
(0.974)\end{array}$ & $* *$ & $\begin{array}{c}0.990 \\
(1.036)\end{array}$ & & $\begin{array}{l}-2.037 \\
(0.464)\end{array}$ & $* *$ \\
\hline 2008 & $\begin{array}{c}10.314 \\
(1.33)\end{array}$ & $* *$ & $\begin{array}{l}10.534 \\
(1.008)\end{array}$ & $* *$ & $\begin{array}{c}2.104 \\
(0.849)\end{array}$ & $* *$ & $\begin{array}{c}-2.131 \\
(0.57)\end{array}$ & $* *$ \\
\hline Unemployment Rate & $\begin{array}{l}0.313 \\
(0.43)\end{array}$ & & $\begin{array}{c}0.689 \\
(0.367)\end{array}$ & $*$ & $\begin{array}{c}-0.015 \\
(0.28)\end{array}$ & & $\begin{array}{c}0.013 \\
(0.314)\end{array}$ & \\
\hline$\%$ Change Job Gains & $\begin{array}{l}-0.398 \\
(0.566)\end{array}$ & & $\begin{array}{l}-0.762 \\
(0.389)\end{array}$ & $*$ & $\begin{array}{l}-0.548 \\
(0.337)\end{array}$ & & $\begin{array}{l}-0.128 \\
(0.417)\end{array}$ & \\
\hline \% Change Job Losses & $\begin{array}{l}-0.235 \\
(0.614)\end{array}$ & & $\begin{array}{l}-0.003 \\
(0.559)\end{array}$ & & $\begin{array}{c}0.068 \\
(0.397)\end{array}$ & & $\begin{array}{c}0.001 \\
(0.464)\end{array}$ & \\
\hline \% Change S\&P 500 & $\begin{array}{l}-0.014 \\
(0.066)\end{array}$ & & $\begin{array}{l}-0.055 \\
(0.057)\end{array}$ & & $\begin{array}{c}0.010 \\
(0.043)\end{array}$ & & $\begin{array}{l}-0.010 \\
(0.045)\end{array}$ & \\
\hline \% Change Retail & $\begin{array}{c}0.218 \\
(0.261)\end{array}$ & & $\begin{array}{l}-0.001 \\
(0.245)\end{array}$ & & $\begin{array}{c}0.201 \\
(0.121)\end{array}$ & & $\begin{array}{c}0.052 \\
(0.166)\end{array}$ & \\
\hline \% Change HPI & $\begin{array}{l}-0.075 \\
(0.044)\end{array}$ & $*$ & $\begin{array}{l}-0.073 \\
(0.037)\end{array}$ & $*$ & $\begin{array}{c}0.057 \\
(0.039)\end{array}$ & & $\begin{array}{l}0.048 \\
(0.023)\end{array}$ & $* *$ \\
\hline Constant & $\begin{array}{c}86.705 \\
(19.748)\end{array}$ & $* *$ & $\begin{array}{c}61.160 \\
(18.056)\end{array}$ & $* *$ & $\begin{array}{l}-0.174 \\
(7.331)\end{array}$ & & $\begin{array}{l}47.551 \\
(8.056)\end{array}$ & $* *$ \\
\hline $\mathrm{R}-\mathrm{sq}$ & 0.063 & & 0.058 & & 0.316 & & 0.066 & \\
\hline $\mathrm{n}$ & 33,761 & & 40,012 & & 92,186 & & 37,584 & \\
\hline
\end{tabular}

Notes: All coefficients estimated with State Fixed Effects.

** Denotes statistical significance at the $5 \%$ level, * at the $10 \%$ level. 
Table 9: Macroeconomic Determinants of Personal and Financial Subjective Probabilities, Interacted with Education

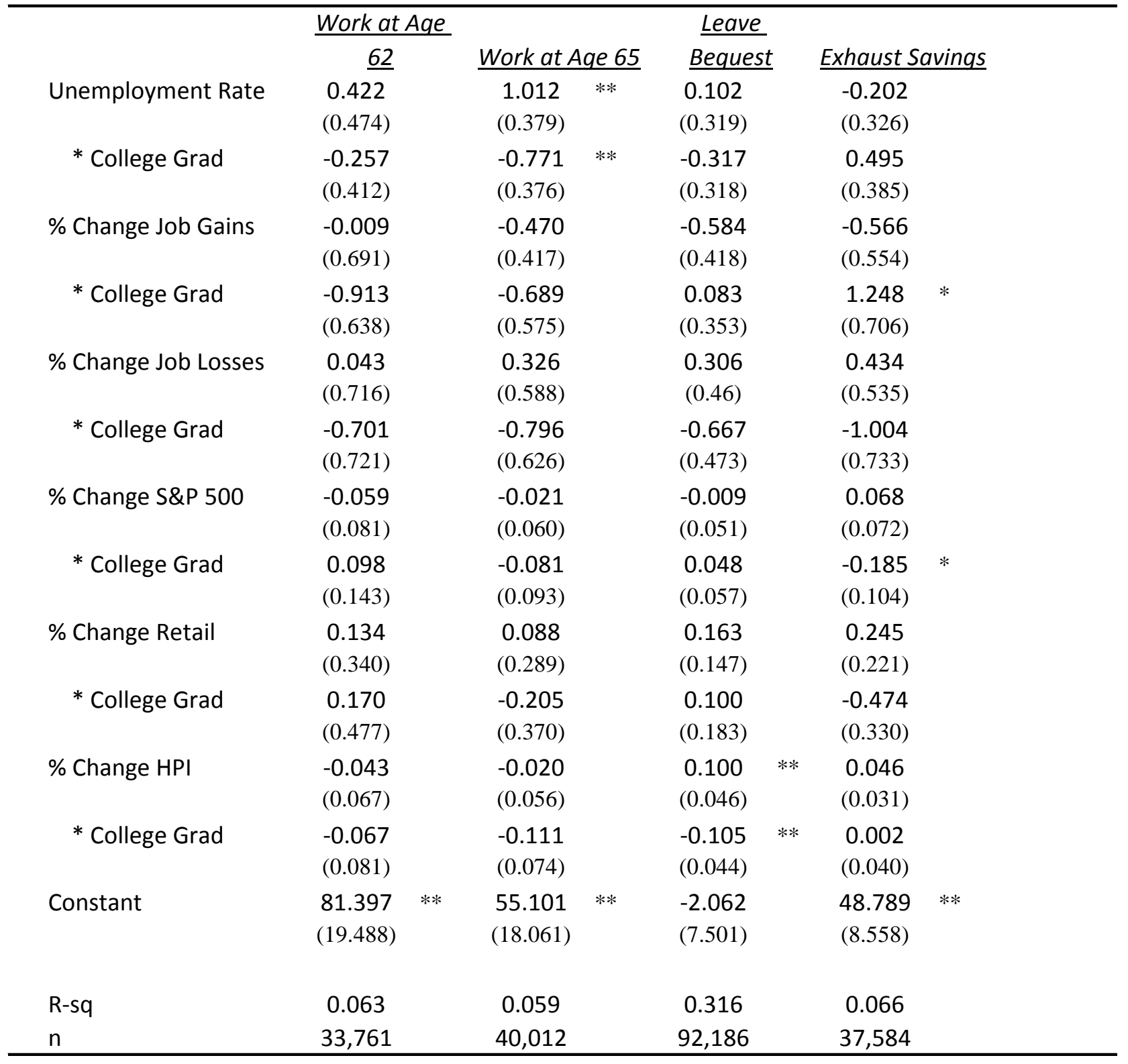

Notes: All coefficients estimated with State Fixed Effects.

** Denotes statistical significance at the $5 \%$ level, * at the $10 \%$ level.

Regressions control for all other covariates listed in Table 2. 


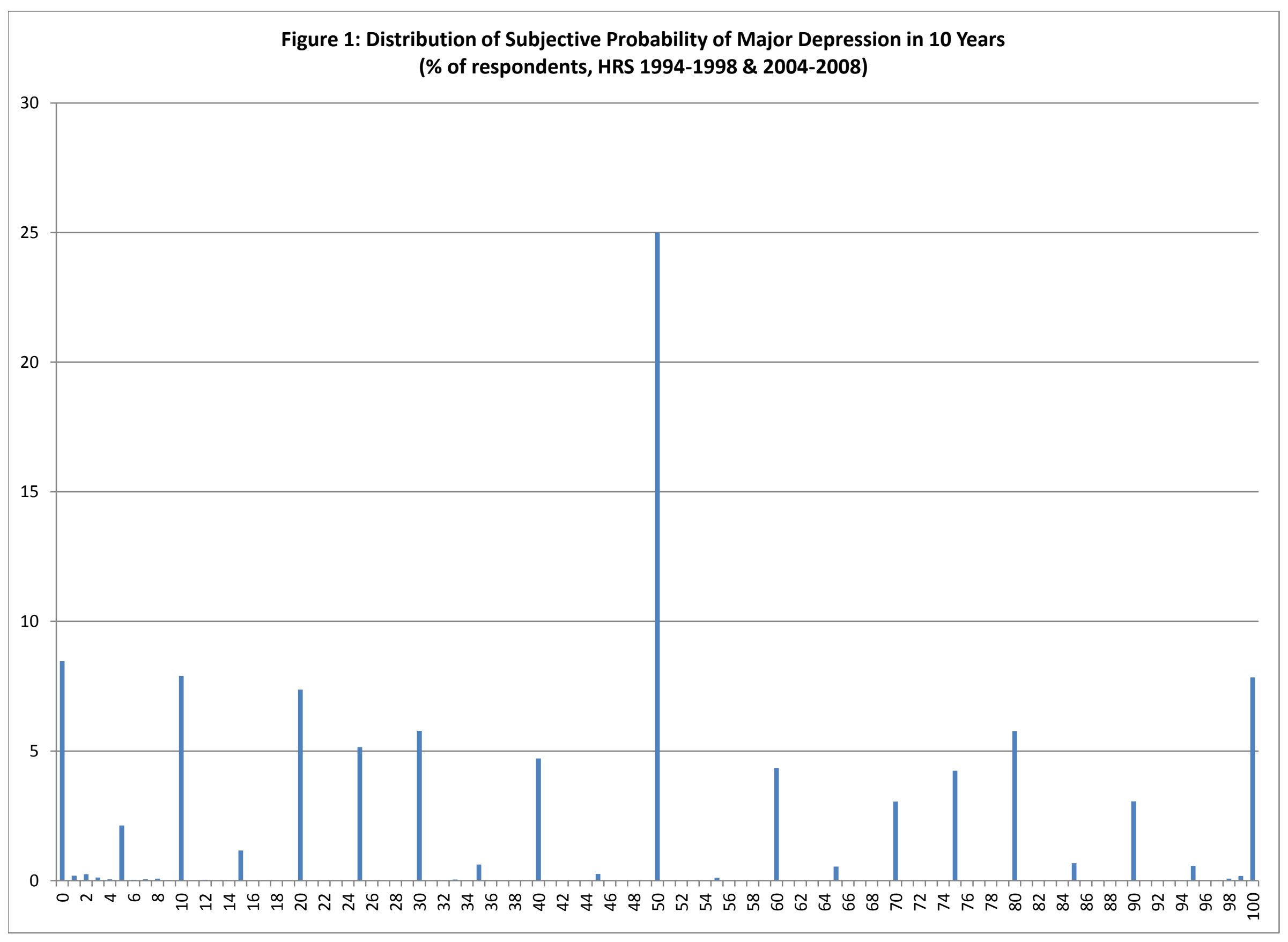


Figure 2: Distribution of Subjective Probability of That Social Security Becomes Less Generous in Five Years (\% of respondents, HRS 1996-1998 \& 2006-2008)

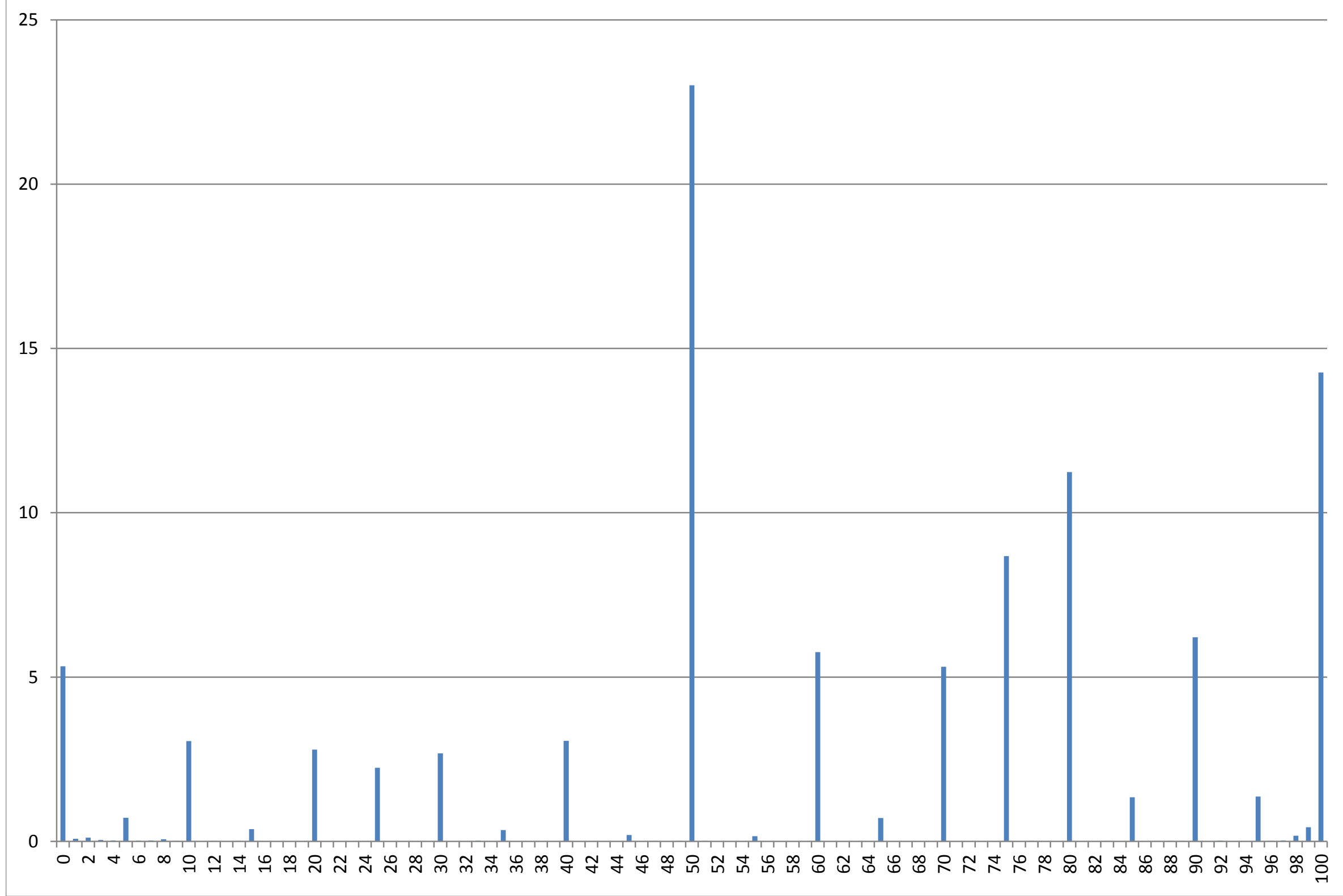




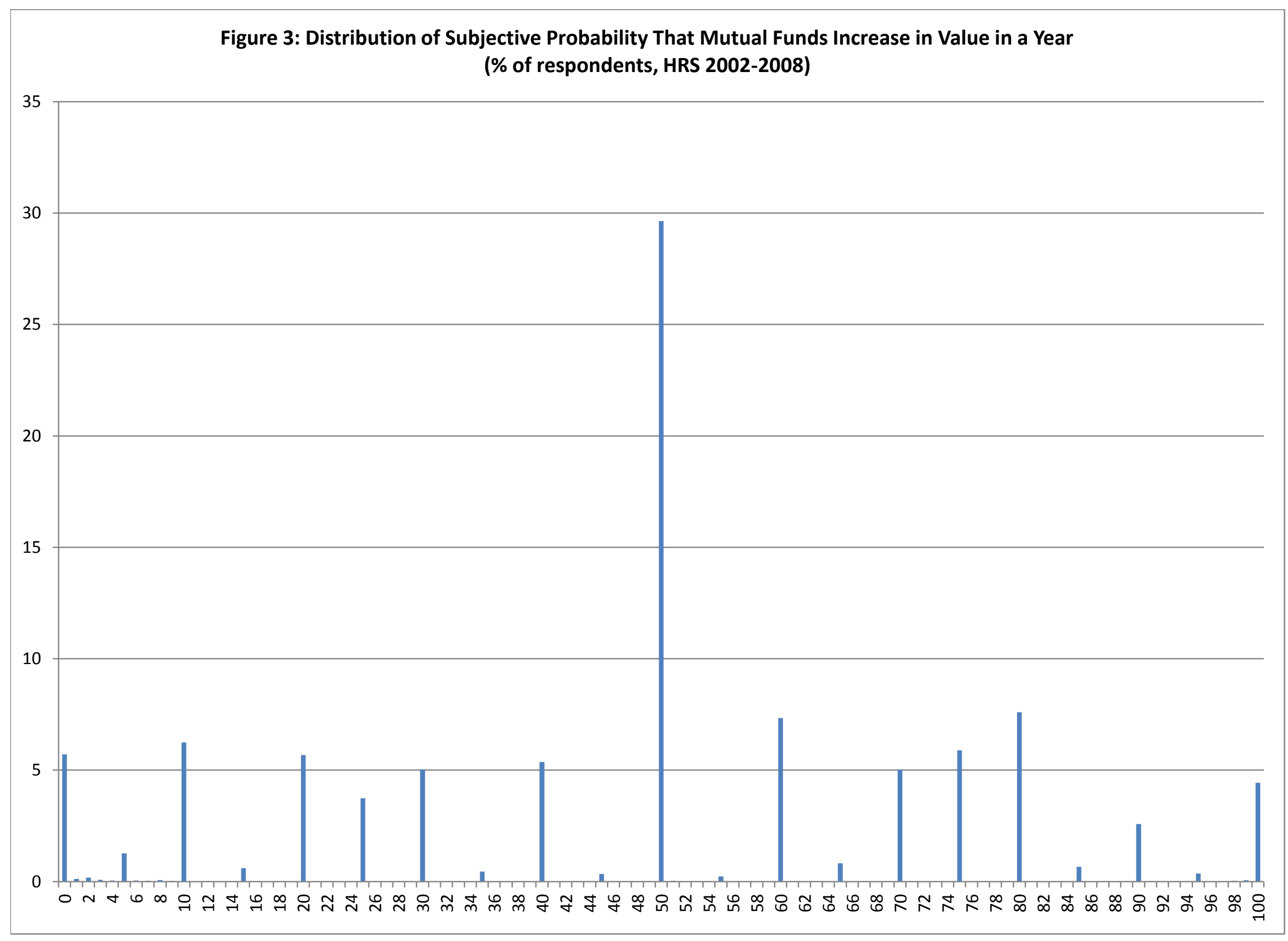




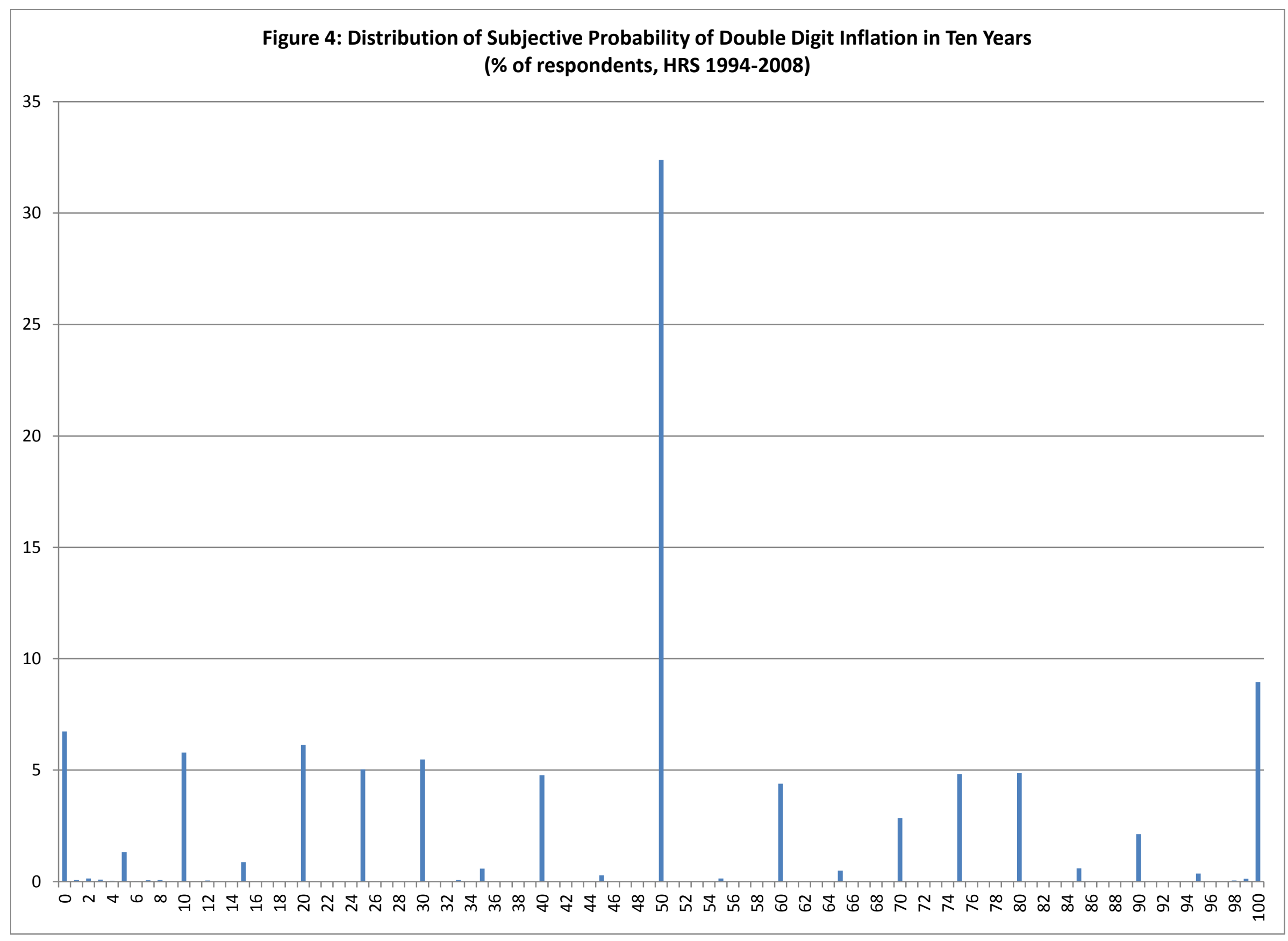


Figure 5: Distribution of Subjective Probability of Working Full-time at Age 62

(\% of respondents <Age 61, HRS 1994-2008)

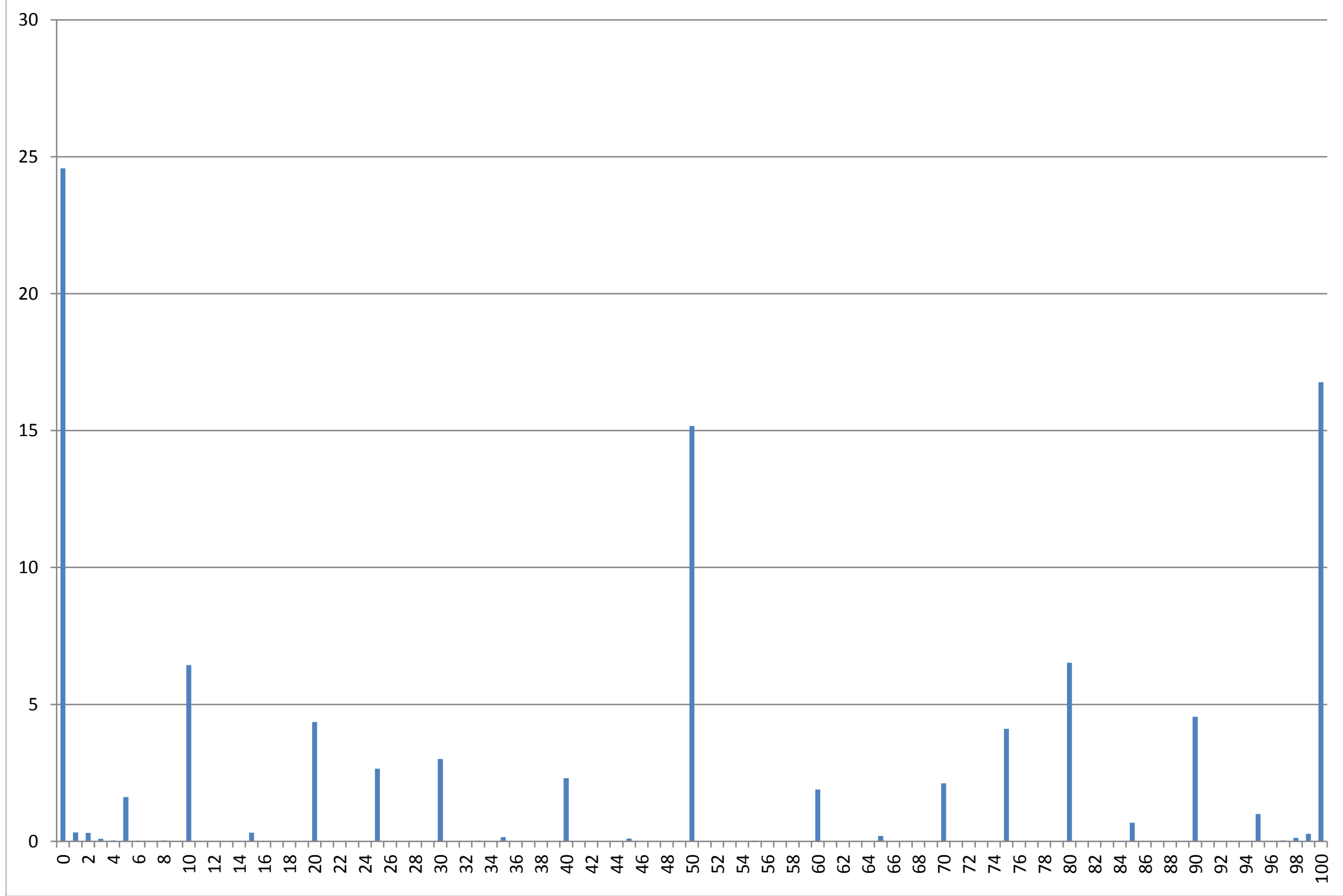




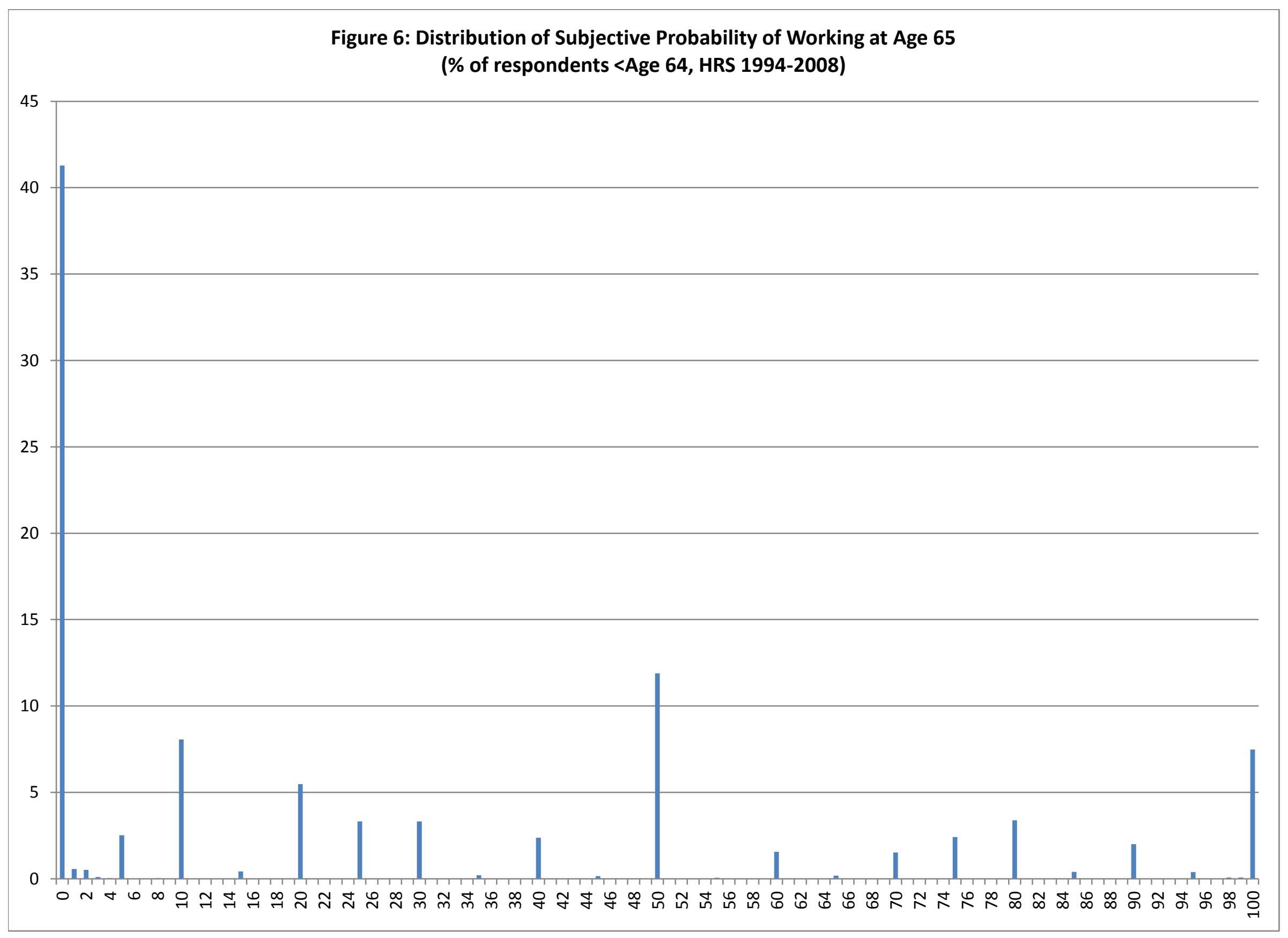




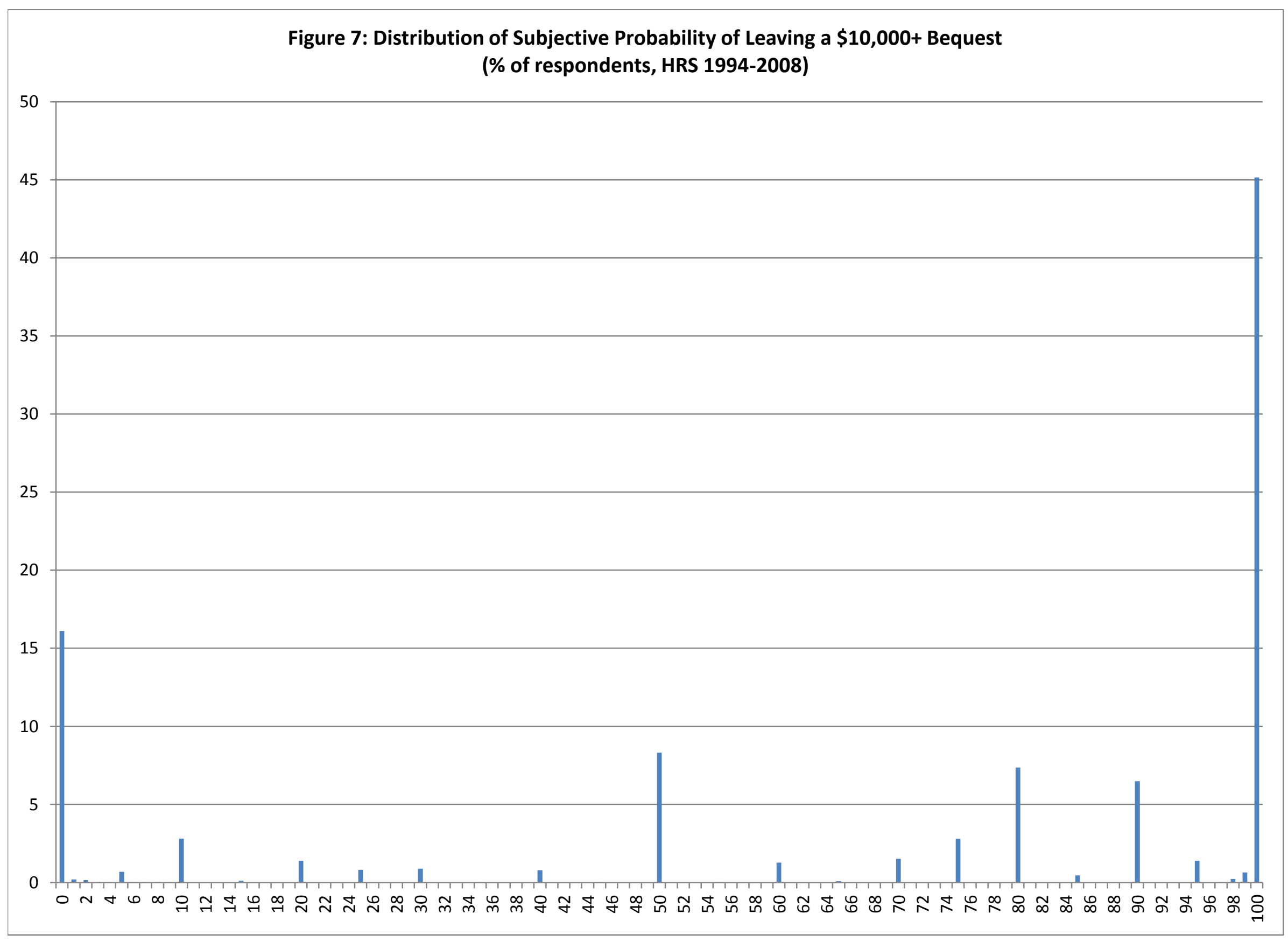




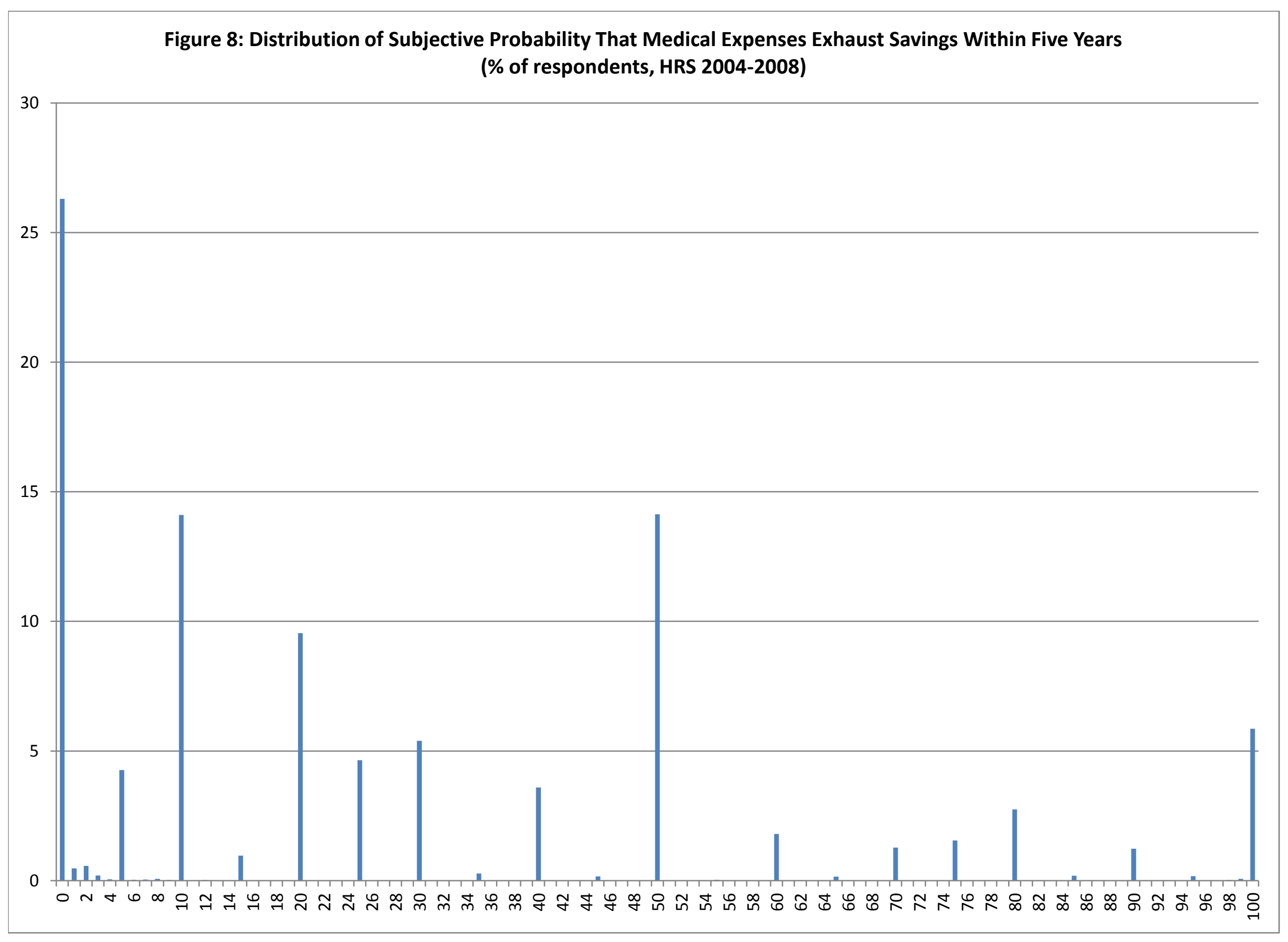

